\title{
Dietary supplementation of black soldier fly (Hermetica illucens) meal modulates gut microbiota, innate immune response and health status of marron (Cherax cainii, Austin 2002) fed poultry-by-product and fishmeal based diets
}

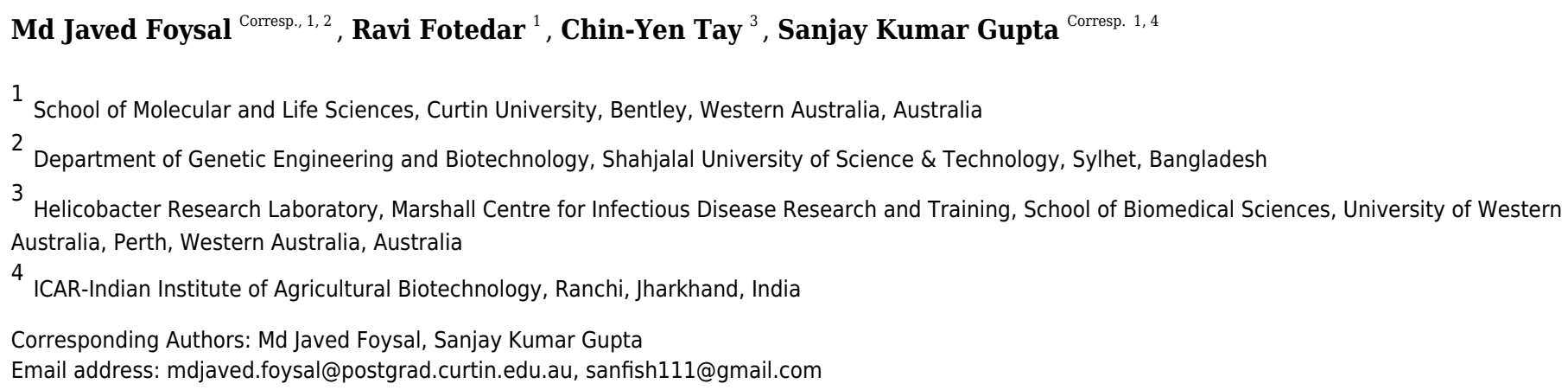

The present study aimed to evaluate the dietary supplementary effects of black soldier fly (Hermetia illucens) (BSF) meal on the bacterial communities in the distal gut, immune response and growth of fresh water crayfish, marron (Cherax cainii) fed poultry-by-product meal (PBM) as an alternative protein source to fish meal (FM). Sixty four marron were randomly distributed into 16 different tanks with a density of four marron per tank. After acclimation, a 60-days feeding trial was conducted on marron fed isonitrogenouts and isocalorific diets containing protein source from FM, PBM, and a combination of FM+BSF and PBM+BSF. At the end of the trial, weight gain and growth of marron were found independent of any dietary treatment, however, the two diets supplemented with BSF significantly $(\mathrm{P}<0.05)$ enhanced haemolymph osmolality $(\mathrm{HO})$, lysozyme activity, total haemocyte counts (THC), and protein and energy contents in the tail muscle. In addition, the analysis of microbiota and its predicted metabolic pathways via 16s rRNA revealed a significantly $(P<0.05)$ higher bacterial activity and gene function correlated to biosynthesis of protein, energy and secondary metabolites in PBM+BSF than other dietary groups. Diets $\mathrm{FM}+\mathrm{BSF}$ and PBM+BSF were seen to be associated with an up-regulation of cytokine genes in the intestinal tissue of marron. Overall, PBM+BSF diet proved to be a superior diet in terms of improved health status, gut microbiota and up-regulated expression of cytokine genes for marron culture. 
1

2

3

4

$5{ }^{1}$ School of Molecular and Life Sciences, Curtin University, Bentley, WA, Australia

$6 \quad{ }^{2}$ Department of Genetic Engineering and Biotechnology, Shahjalal University of Science and

7 Technology, Sylhet, Bangladesh

$8 \quad{ }^{3}$ Helicobacter Research Laboratory, Marshall Centre for Infectious Disease Research and

9 Training, School of Biomedical Sciences, University of Western Australia, Perth, WA, Australia

\section{Dietary supplementation of black soldier fly (Hermetica illucens) meal modulates gut} microbiota, innate immune response and health status of marron (Cherax cainii, Austin 2002) fed poultry-by-product and fishmeal based diets

Md Javed Foysal ${ }^{1,2^{*}}$, Ravi Fotedar ${ }^{1}$, Chin-Yen Tay ${ }^{3}$, Sanjay Kumar Gupta ${ }^{1,4^{*}}$

${ }^{4}$ ICAR-Indian Institute of Agricultural Biotechnology, Ranchi, Jharkhand, India

${ }^{*}$ Corresponding author:

Md Javed Foysal

School of Molecular and Life Science, Curtin University, Bentley, WA, Australia

Email address: mjfoysal-geb@sust.edu or mdjaved.foysal@postgrad.curtin.edu.au

Telephone: +6189266 4508: Mobile +61451404337

ORCID: $\underline{\text { https://orcid.org/0000-0002-2064-8897 }}$

${ }^{*}$ Corresponding author:

Sanjay Kumar Gupta

ICAR-Indian Institute of Agricultural Biotechnology, Ranchi, Jharkhand, India

Email address: $\underline{\text { sanfish111@gmail.com }}$ 


\section{ABSTRACT}

The present study aimed to evaluate the dietary supplementary effects of black soldier fly (Hermetia illucens) (BSF) meal on the bacterial communities in the distal gut, immune response and growth of fresh water crayfish, marron (Cherax cainii) fed poultry-by-product meal (PBM) as an alternative protein source to fish meal (FM). Sixty four marron were randomly distributed into 16 different tanks with a density of four marron per tank. After acclimation, a 60-days feeding trial was conducted on marron fed isonitrogenouts and isocalorific diets containing protein source from FM, PBM, and a combination of FM+BSF and PBM+BSF. At the end of the trial, weight gain and growth of marron were found independent of any dietary treatment, however, the two diets supplemented with BSF significantly $(\mathrm{P}<0.05)$ enhanced haemolymph osmolality $(\mathrm{HO})$, lysozyme activity, total haemocyte counts (THC), and protein and energy contents in the tail muscle. In addition, the analysis of microbiota and its predicted metabolic pathways via 16s rRNA revealed a significantly $(\mathrm{P}<0.05)$ higher bacterial activity and gene function correlated to biosynthesis of protein, energy and secondary metabolites in PBM+BSF than other dietary groups. Diets FM+BSF and $\mathrm{PBM}+\mathrm{BSF}$ were seen to be associated with an up-regulation of cytokine genes in the intestinal tissue of marron. Overall, PBM+BSF diet proved to be a superior diet in terms of improved health status, gut microbiota and up-regulated expression of cytokine genes for marron culture. 
43

44

45

46

47

\section{INTRODUCTION}

Fish meal (FM) is one of the major sources of dietary protein for cultured aquatic animals, posing an increasing challenge on the reduction of feed cost and wild fish stocks (Tacon \& Metian, 2008). Recent reports revealed the global decline of fishmeal production due to the increasing demand of wild stocks in contrast to amount of fish harvested for trashing (Cashion et al., 2017; Pauly \& Zeller, 2017). It is an utmost priority to find a suitable, cheap and widely available alternative to fishmeal to meet-up the burgeoning demand of feed for the sustainable aquaculture industry. On the other hand, poultry-by-products meal (PBM) is a solidified by-product from poultry processing industry that has high potential to be incorporated into aqua-diets as a substitute for fishmeal (Saoud et al., 2008). PBM is readily available worldwide and is more economical when compare with FM (Emre, Sevgili \& Diler, 2004; Wu et al., 2018). PBM alone or in combination with bone, feather, and blood meal, can be one of the major protein source in aqua-diets owing to high protein, suitable fatty acids, vitamins, and minerals, (Dozier, Dale \& Dove, 2003; Fuertes et al., 2013). In addition, PBM is reported to have positive effect on the growth rate, digestibility, and immune status of fish and crayfish (Bransden, Carter \& Nowak, 2001; Yang et al., 2006; Saoud et al., 2008). The black soldier fly (BSF) larvae, another alternative to fishmeal protein source, is gaining increasing popularity for aquaculture industry (Stamer et al., 2014). BSF contains high protein and fat, rich in trace elements, and more importantly, has a lesser impact on the environment and hence named as "savior" in the food-insecure world (Wang \& Shelomi, 2017). The efficacy of BSF as an alternative protein source for warm-water fish has been validated in earlier studies (Stankus, 2013; Stamer et al., 2014; Wang \& Shelomi, 2017), however limited data are currently available on the suitability of using BSF as alternative protein source and its supplementary effect on other 
65 sources of protein, including FM and PBM in aqua-diets (St-Hilaire et al., 2007; Kroeckel et al., 66 2012).

67 Marron (Cherax cainaii) is one of the largest freshwater crayfish endemic to Southern part of 68 Western Australia (WA) (DoF, 2010; Foysal et al., 2019b). Marron is popular for its distinctive 69 flavor and taste and therefore considered as an iconic freshwater crayfish in WA. Marron farming 70 possesses a number of advantages over other crayfish species (C. destructor, $C$. preissii and $C$. crassimanus) including disease resistance, high market demand and price, and possible live shipment to long distances etc. (Lawrence, 2007). Yet, the production has remained stagnant over the decade (Mai \& Fotedar, 2018). To improve the production potential, several investigations have been conducted to find the suitable combination of feed for marron (Ambas, Suriawan \& Fotedar, 2013; Ambas \& Fotedar, 2015; Ambas, Buller \& Fotedar, 2015). As an omnivorous animal, the protein requirement for marron is moderate (approximately 30\%) (Ambas, Fotedar \&

77 Buller, 2017). Therefore, a combination of PBM and BSF can be ideal alternative protein source in marron diet.

Crayfish harbour complex bacterial communities in the gut that influences various host functions like digestion, nutrition, immunity, and disease resistance (Skelton et al., 2017; Zoqratt et al., 2018). Due to their vital roles, enrichment of some bacterial communities in the gut with dietary feed supplementation has been validated to accelerate the growth and immune status of the crayfish (Anuta et al., 2011; Safari \& Paolucci, 2018). High relative abundance of lactic acid bacteria, especially Bacillus, Lactobacillus in the gut are described to have beneficial influences on the health and immunity of white shrimp (Liptopenaeus vannamei) (Zokaeifar et al., 2012), zebrafish

86 (Danio rerio) (Falcinelli et al., 2015), Atlantic salmon (Salmo salar) (Gajardo et al., 2017) and 87 northern snakehead (Channa argus) (Miao et al., 2018). 
88 Recent advancement in 16S rRNA based high throughput sequencing techniques has enabled

89 precise detection of gut microbial communities of fish. This technology has been successfully

90 employed to analyze the feeding effects on the gut bacterial populations of fish in earlier reports

91 (Gajardo et al., 2017; Miao et al., 2018). In addition, quantitative real-time PCR is routinely used

92 for the measurement of relative expression level of immune genes to infer the effect of feed on the

93 immunity of crayfish (Shekhar, Kiruthika \& Ponniah, 2013; Jiang et al., 2015a). This study aimed

94 to characterize the bacterial communities in the distal gut of marron fed FM, PBM, a combination

95 of $\mathrm{FM}+\mathrm{BSF}$ and $\mathrm{PBM}+\mathrm{BSF}$ and analyze the expression patterns of some cytokine genes.

96

97

98

\section{MATERIALS AND METHODS}

\section{Experiment set-up}

A total of 64 marron $(65.01 \pm 5.09 \mathrm{~g})$ were procured from Blue Ridge Marron, Manjimup, Western Australia $\left(34.2019^{\circ} \mathrm{S}, 116.0170^{\circ} \mathrm{E}\right)$ and transported live to Curtin University Aquatic Research Laboratory (CARL), Technology Park, Bentley, Western Australia. Marron were then distributed into 16 different tanks (80 cm diameter and $50 \mathrm{~cm}$ height, $250 \mathrm{~L}$ capacity) filled with $150 \mathrm{~L}$ of fresh water and acclimated for 14 days before commencement of the trial. Constant aeration was provided by air diffusers (Aqua One, Perth, Australia) and fixed temperature $\left(22 \pm 0.5^{\circ} \mathrm{C}\right)$ was maintained using submersible thermostat set (Aqua One, Perth, Australia). Water quality parameters including $\mathrm{pH}$, dissolved oxygen, nitrate, nitrate, and ammonia were maintained within the suitable range for marron culture as reported previously (Ambas, Fotedar \& Buller, 2017) (DatasetS1). The $\mathrm{pH}$ and temperature of the water were measured using portable waterproof ${ }^{\circ} \mathrm{C} / \mathrm{mV} / \mathrm{pH}$ meter (CyberScan $\mathrm{pH} 300$, Eutch Instruments, Singapore) while dissolved oxygen (DO) concentration was measured using digital DO meter (YSI55, Perth Scientific, Australia). The concentration of nitrate, nitrite and ammonia in water were monitored using Hach DR/890 
111 Colorimeter (Hach, Loveland, Colorado, USA). Approximately 30\% of water from each tank was

112 exchanged twice a week after siphoning out the faecal wastes. Each marron was nurtured in a

113 separate cage prepared of plastic mesh $(0.8-8.0 \mathrm{~mm}$ thickness) to avoid cannibalism (Ambas,

114 Fotedar \& Buller, 2017). During acclimation, marron were fed every day at afternoon with

115 standard basal marron diet composed of $29 \%$ crude protein, $9 \%$ crude fat, $8.5 \%$ moisture, and $5 \%$

116 crude ash, prepared by Glenn Forest, Western Australia.

\section{Test diets and the experimental design}

118 Four isoproteic and isocalorific diets containing fishmeal (FM), poultry-by-product meal (PBM),

119 fishmeal supplemented with black soldier fly meal (FM+BSF), and poultry-by-product meal 120 supplemented with black soldier fly meal (PBM+BSF) were prepared (Table 1). The ingredients

121 were supplied by Glenn Forrest, Western Australia and after feed formulation the test diets were

122 also prepared by the same company. Proximate compositions of each diet was determined as per

123 the method of Association of Official Analytical Chemists, AOAC (AOAC, 2006). Four randomly

124 assigned tanks, with four individually held marron in cages, were given each test diet, hence using

125 a design of four dietary treatments X 4 replicates per dietary treatment. Each marron in a cage was

126 fed the respective diets, once every day at 12 PM.

\section{Marron sampling}

128 For haemolymph, health indices and gene expression analysis, 16 marron, one marron randomly

129 selected from each tank was used. However, for DNA extraction, nine randomly selected marron

130 from three randomly selected tanks from each treatment, were selected. No samples were collected

131 from one of the tanks from each treatment.

\section{Analysis of growth, hemolymph parameters and health indices}


133 At the end of the experiment, the marron growth was measured by using the following formulas:

134 Weight gain, $\mathrm{WG}=[($ mean final body weight - mean initial body weight $)] /[$ mean initial body

135 weight $]$; and Specific growth rate, SGR $(\% /$ day $)=[($ mean final body weight - in mean initial body 136 weight)/number of days] $\times 100$.

137 The haemolymph osmolality was measured (Sang \& Fotedar, 2004) at $96 \mathrm{~h}$ intervals. Haemolymph

$138(0.05 \mathrm{~mL})$ from each marron was extracted carefully from the pericardial cavity using $0.5 \mathrm{~mL}$ 139 syringe containing a $0.1 \mathrm{~mL}$ of precooled anticoagulant $(0.1 \%$ glutaraldehyde in $0.2 \mathrm{M}$ sodium 140 cacpodylate, $\mathrm{pH} 7.0 \pm 0.2$ ). The osmolality of the hemolymph and anticoagulant mix solution was 141 measured by Cryoscopic Osmometer-Osmomet 030 (Gonotec, Berlin, Germany).

142 Similarly, the haemolymphatic lysozyme activity was measured using turbid-metric assay, as 143 described by Mai \& Fotedar, 2018. Fifty microliters of anticoagulant added hemolymph sample 144 were dispersed into 96-well microtiter-plate (Iwaki, Tokyo, Japan). After 15 min incubation, 50 $145 \mu \mathrm{L}$ of PBS (0.25 mg/mL) suspended Micrococcus lysodeiktikus (Sigma-Aldrich, St. Louis, MO, 146 USA) solution was added into separate wells of the same plate. The absorbance of each well in the 147 plate was then monitored at two min intervals for $20 \mathrm{~min}$ (10 times) at $450 \mathrm{~nm}$ wavelength in 148 MS212 reader (Titertek Plus, Tecan, Grodig, Austria). The lysozyme activity unit was defined as 149 the amount of enzyme consumed in a reduction absorbance of $0.0001 / \mathrm{min}$. The lysozyme activity 150 was expressed as enzyme units/mL of haemolymph $(\mathrm{U} / \mathrm{mL})$.

151 Similar to above parameters, to measure total haemocyte counts (THC), $0.2 \mathrm{~mL}$ of marron 152 haemolymph was suspended in $0.2 \mathrm{~mL}$ of anticoagulants. THC was calculated for each marron 153 under a hemocytometer (Nauabuer, Germany) with 100X magnification (Ambas et al., 2016). 
154 The amount of protein and energy in the tail muscle and crude fat in the hepatopancreas of marron 155 was measured using methods described by the Association of Official Analytical Chemists, AOAC 156 international (AOAC, 2006). Crude protein was measured following the Kjeldahl method (N× 157 6.25) using sulfuric acid $\left(\mathrm{H}_{2} \mathrm{SO}_{4}\right)$ and copper catalyst tablets in Kjeltec Auto 1030 analyzer (Foss 158 Tecator, Höganäs, Sweden). The percentage of crude fat in marron hepatopancreas was calculated 159 using Soxhlet ether extraction method using Soxtec System HT6 (Tecator, Höganäs, Sweden), as 160 described earlier (Jim, Garamumhango \& Musara, 2017). The total gross energy in the dried tail 161 muscle content was determined by using bomb calorimeter (Heitersheim, Germany). The hepatopancreas index of marron after feeding trial was calculated using the formula:

Hepatopancreas index $(\mathrm{HI})=$ Hepatopancreas dry weight/ (body dry weight excluding large cheliped x 100).

DNA extraction, PCR, and high throughput sequencing

At the end of the experiment, randomly selected marron were taken into biosafety cabinet followed by careful excision of the guts. Then the hindgut were separated and the gut contents of three marron from each tank were homogenized, pooled together, and transferred in to $1.5 \mathrm{~mL}$ of Eppendorf. The bacterial DNA from the hindgut sample was extracted using DNeasy Blood and Tissue Kit (Qiagen, Crawley, UK) following the manufacturer's instructions. Extracted DNA was quantified using NanoDrop spectrophotometer (Thermo Fisher Scientific, Waltham, MA, USA) and diluted eventually to $30 \mathrm{ng} / \mu \mathrm{L}$ final concertation. PCR master mixture was prepared as $50 \mu \mathrm{L}$ final concentration containing $25 \mu \mathrm{L}$ Hot Start 2X Master Mix (BioLab Inc., Australia), $2 \mu \mathrm{L}$ of

174 template DNA, $1 \mu \mathrm{L}$ of each forward and reverse V3-V4 sequencing primers, and $21 \mu \mathrm{L}$ of nuclease-free water. The PCR was performed using BioRad S100 Gradient Thermal Cycler (Bio- 
177 denaturation at $94{ }^{\circ} \mathrm{C} ; 30$ cycles of denaturation $\left(30 \mathrm{~s}\right.$ at $\left.94{ }^{\circ} \mathrm{C}\right)$, annealing $\left(1 \mathrm{~min}\right.$ at $\left.55^{\circ} \mathrm{C}\right)$, and 178 extension $\left(1 \mathrm{~min}\right.$ at $\left.68^{\circ} \mathrm{C}\right)$; a final extension at $68^{\circ} \mathrm{C}$ for $5 \mathrm{~min}$ and holding the temperature at 10 $179{ }^{\circ} \mathrm{C}$. The primers set, obtained from Illumina protocol (Part \# 15044223 Rev. B) 16sF 5'180 TCGTCGGCAGCGTCAGATGTGTATAAGAGACAGCCTACGGGNGGCWGCAG and 16sR 5’-GTCTCGTGGGCTCGGAGATGTGTATAAGAGACAGGACTACHVGGGTATCTAATCC

182 were used to amplify the $16 \mathrm{~s}$ V3-V4 region. Amplified PCR products were separated by $1 \%$ 183 agarose gel electrophoresis (Bio-Rad Laboratories Inc., California, USA) and visualized under gel 184 doc (FujiFilm LAS-4000 Image Analyzer, Boston Inc., Foster City, California, USA). The 16S rRNA PCR amplicon of each sample was barcoded via a secondary PCR according to the Illumina standard protocol (Part \# 15044223 Rev. B). Each sample was sequenced up to 50,000 reads on an Illumina MiSeq platforms (Illumina Inc., San Diego, California, USA) at Harry Perkins Institute of Medical Research, Western Australia, using Illumina MiSeq Reagent v3 kit (600 cycles, Part \# MS-102-3003).

\section{Quantitative real-time PCR}

In this study, five cytokine genes (IL-1 $\beta$, IL-8, IL-10, IL-17F, and TNF- $\alpha$ ) associated with immunity of fish and crayfish (Miao et al., 2018), and two reported crayfish tissue genes, vitellogenin $(V g)$ and proliferating cell nuclear antigen (Pcna) (Jiang et al., 2015b) were selected 194 for qRT-PCR to measure the relative expression patterns after feeding trial. The whole intestine tissue samples were collected aseptically, chopped into small pieces, and preserved into RNA Later solution (Sigma-Aldrich, Germany) according to manufacturer's instructions. After thawing and homogenized tissue samples were used for RNA extraction using RNeasy Mini Kit (Qiagen, 
200 DNA impurities. Extracted RNA was checked for quality and quantity in 1\% agarose gel and

201 NanoDrop spectrophotometer, respectively (Thermo Fisher Scientific, USA). The cDNA library

202 from the extracted RNA was prepared using Omnicript RT kit (Qiagen, Hilden, Germany).

203 Quantitative real-time PCR to measure the relative expression level of eight genes was performed

204 using PowerUp ${ }^{\mathrm{TM}}$ Cyber Green Master Mix (Thermo Scientific, USA) with 7500 Real-Time PCR

205 System (Applied Biosystems, USA). The relative expression of each target gene was calculated

206 using the $2^{-\Delta \Delta \mathrm{CT}}$ method, after normalisation against the $\beta$-actin reference gene (Miao et al., 2018).

207 Duncan's multiple range test was used to compare the relative expression level of genes for FM to

208 each of the others (PBM, FM+BSF, and PBM+BSF).

209 Bioinformatics

210 The initial quality of 16S rRNA sequences was checked in fastQC pipelines (Andrews, 2010). The

211 sickle program was used for quality trimming of sequencing reads. Following trimming, reads of

212 less than $200 \mathrm{bp}$ were discarded (Joshi \& Fass, 2011). MeFiT pipeline was then used for the

213 merging of overlapping paired-end reads with default parameters (Parikh et al., 2016). Filtering of

214 chimeric sequences, open reference clustering of $16 \mathrm{~S}$ rRNA sequences into Operational

215 Taxonomic Units (OTUs) at 97\% similarity threshold and removal of singleton OTUs were

216 conducted using micca otu (version 1.7.0) (Albanese et al., 2015). Taxonomic assignment of the

217 representative OTUs was performed using mica classify against SILVA 1.32 database clustered at

218 97\% identity (Quast et al., 2013). Multiple sequence alignment of the representative OTUs was

219 done using PASTA algorithm (Mirarab et al., 2015). Non-metric multidimensional scaling

220 (nMDS) of bacterial OTUs from four different groups was done in PAST statistical software

221 package (Hammer, Harper \& Ryan, 2009). The Shannon, Simpson, and Fisher alpha diversity

222 indices were calculated using "vegan" package in R (Oksanen et al., 2018). Chaol diversity in the 
223 samples was calculated using formula $S_{\text {chao } 1}=S_{\text {obs }}+(n 1)^{\downarrow} / 2 n 2$, where $S_{\text {obs }}=$ number of observed

224 genera, $\mathrm{n} 1=$ number of singletons (genus captured once), $\mathrm{n} 2=$ number of doubletons (genera

225 captured twice) (Militon et al., 2010). Venn diagram for bacterial abundance regarding diversity

226 at genus level was generated using FunRich (v3.1.3) (Benito-Martin \& Peinado, 2015). Linear

227 Discriminant Analysis Effect Size, LEfSe (University of Auckland, New Zealand) was applied to

228 find the indicator bacterial groups in four different feeding groups with a minimum logarithmic

229 LDA cut-off value of 8.0. For predicting differentially abundant metabolic pathway in four 230 different groups, Piphillin algorithm (http://secondgenome.com/Piphillin) was used with supports 231 of KEGG database, BioCyc (v21), and LEfSe (LDA 3.0) (Iwai et al., 2016). Numerical growth 232 and health indices data for marron were analyzed using SPSS IBM (v23, 2017). One way analysis 233 of variance (ANOVA) was used to calculate any significant differences $(\mathrm{P}<0.05)$ among variables 234 in four different dietary treatments.

\section{RESULTS}

\section{Effects of four different feed on marron health indices}

237 No significant $(\mathrm{P}>0.05)$ weight gain and growth rate were observed in $\mathrm{PBM}$ and two BSF 238 supplemented diet (FM+BSF and PBM+BSF) compared to FM (Table 2, DatasetS2). The effects 239 of dietary PBM was found to be almost similar to FM on marron health and immunity. Both BSF 240 (FM+BSF and PBM+BSF) supplemented diets showed significant enhancement in protein, 241 energy, lysozyme, and THC. However, the diet $\mathrm{PBM}+\mathrm{BSF}$ showed a significant $(\mathrm{P}<0.05)$ 242 influence on the energy content in tail muscle, and significantly pronounced $(\mathrm{P}<0.005)$ effects of 243 PBM+BSF was recorded for tail muscle protein, lysozyme, THC and HO (Table 3, DatasetS3). 244 Dietary incorporation of BSF with $\mathrm{PBM}$ also showed a significant $(\mathrm{P}<0.05)$ decline in $\mathrm{HI}$ and fat 
245 content of hepatopancreas whereas both BSF (FM+BSF and PBM+BSF) supplemented diets

246 showed significant enhancement in protein, energy, lysozyme, and THC.

247 Bacterial diversity in the hindgut after feeding trial

248 At the end of the trial, all the four experimental diets displayed distinct effect on different bacterial

249 populations of marron hindgut (Figure 1(A)). Quality filtering obtained 377,848 high-quality

250 reads which were assigned into 119 genera. The number of the shared and unique genera were

251 found to be significantly $(\mathrm{P}<0.05)$ higher in $\mathrm{PBM}+\mathrm{BSF}$ fed marron than the other marron groups

252 (Figure 1(B)). At genus level, Proteobacteria (46.62-92.88\%) was found to be dominant in FM,

253 PBM, and FM+BSF dietary groups whereas significantly $(\mathrm{P}<0.05)$ higher abundance for 254 Firmicutes (63.52-92.88\%) was recorded in PBM+BSF fed group (Figure 2(A)). Next to 255 Proteobacteria, Fusobacteria (36.74-39.15\%) and Tenericutes (20.28-39.77\%) were the second 256 abundant phyla in FM and FM+BSF fed marron, respectively. In the PBM+BSF fed marron, 257 Fimicutes profusion (25.18-42.37\%) was recorded, followed by Proteobacteria (28.4-33.6\%), 258 and Bacteroidetes $(10.54-11.8 \%)$. Compared to FM, the other diets showed a significant $(\mathrm{P}<0.05)$ 259 increase in the diversity of bacteria at genus level whereas, the BSF supplemented diet, the marron 260 displayed higher abundance. At genus level, Hypnocyclicus (46.31-47.81\%), Aeromonas 261 (39.93-58.5\%), Candidatus Bacilloplasma (27.88-40.65\%), and Streptococcus (17.77-24.38\%), 262 were the most dominant bacteria in FM, PBM, FM+BSF, and PBM+BSF fed marron, respectively 263 (Figure 2(B)). The relative abundance level for Vibrio was found to decrease significantly in 264 PBM+BSF (1.13-2.42\%) groups than FM (16.6-38.9\%) fed group. The abundance of Serratia and 265 Enterobacter dropped to zero in PBM+BSF fed marron whereas, FM fed marron had Serratia and 266 Enterobacter in abundance of $2.99-5.0 \%$ and $1.58-2.57 \%$, respectively. Among the top 20 267 abundant genera, Polynucleobacter, Limnohabitans, Flavobacterium, Shewanella, 
268 Corynebacterium, Ezakiella, Porphyromonas, hgcl clade, Anaerococcus, Rhodobacter, and

269 Lactovum were present in PBM+BSF group than FM fed group. The Fisher Alpha and Chao1

270 diversity indices of PBM+BSF diet group were significantly $(\mathrm{P}<0.05)$ higher than the FM group.

271 The Simpson and Shannon indices were also found to be augmented in PBM+BSF fed marron,

272 however, at higher significance level, $\alpha$-level of 0.005 and 0.001 , respectively (Table 4). In

273 contrast, only Chaol diversity index was significantly improved in PBM and Fisher alpha in

274 FM+BSF fed marron, respectively.

275 LEfSe based microbial lineages and metabolic pathways in four different groups

276 The results of Linear Discriminant Analysis Effect Size (LEfSe) revealed 21 genus which were

277 significantly modulated in three different dietary groups (FM, PBM, and PBM+BSF) at LDA cut-

278 off value of 8.0 based on Wilcoxon non-parametric $t$-test corrected for multiple hypothesis testing

$279(\mathrm{P}<0.05)$. Out of 21,16 genera showed to be enriched in $\mathrm{PBM}+\mathrm{BSF}$ fed marron including species

280 from Lactobacillus, Streptococcus, Bacteroidetes, Aquabacterium, Actinobacteria etc. (Figure 3).

281 Significantly $(\mathrm{P}<0.05)$ increased bacteria at genus level in $\mathrm{PBM}$ fed group were Aeromonas and

282 Limnohabitans. Hafnia Obesumbacterium, Citrobacter and Serratia were found to be enriched in

283 FM fed marron while no genus was exhibited to be significantly $(\mathrm{P}>0.05)$ higher in FM+BSF fed

284 marron at stringent cut-off value. LEfSe cladogram revealed significantly $(\mathrm{P}<0.05)$ enriched 46

285 taxa (phylum to genus) in three different dietary groups. No significant enrichment was observed

286 in FM+BSF group at a strict cut-off value (LDA 4.0), where 39 were significantly enriched after

287 fed PBM+BSF diet (Figure 4). The microbial lineages in PBM+BSF fed marron were exclusively

288 enriched from the phylum Firmucutes, Bacteroides, and class Bacilli, Negativicutes whereas in the

289 FM and FM+BSF fed group, the enriched lineages were mostly from the Proteobacteria phylum.

290 Differences in predicted functional pathways based on the bacterial abundance exhibited to be 
291 associated with carbohydrate metabolism and transport among the FM fed marron, fatty acid

292 biosynthesis and metabolism among PBM fed marron, galactose metabolism and aminoacyl tRNA

293 biosynthesis among FM+BSF feed group, and amino acid biosynthesis and energy metabolism in

294 PBM+BSF fed marron (Figure 5).

\section{The relative expression level of genes}

296 The relative expression level of seven different genes in four different dietary groups are shown in

297 Figure 6. Compared to FM dietary group, the BSF supplemented (FM+BSF and PBM+BSF)

298 marron gut displayed significant $(\mathrm{P}<0.05)$ up-regulation of IL-1 $\beta$, IL-10, IL-17F, TNF- $\alpha$, and

299 down-regulation of $V g$ genes in terms of fold change in contrast to $\beta$-actin reference gene after 60

300 days of feeding trial. The expression of cytokine genes, however, was found to be significantly up-

301 regulated in PBM+BSF fed group. The normalised data showed the highest mean expression for

302 IL-17F, followed by IL-10, IL-1 $\beta$, and TNF- $\alpha$, respectively. The relative expression level of IL-8

303 and Pcna were relatively stable in three different protein fed groups while $V g$ expression was found

304 to be decreased significantly with PBM and two BSF supplemented diets at the end of the trial.

\section{Data availability}

306

307

308

309

310

311

312

The raw sequence data in FASTQ files are currently available at National Centre for Biotechnology Information (NCBI) BioProject under the accession number PRJNA504966.

\section{DISCUSSION}

In aquaculture practice, replacement of dietary fishmeal with alternative cheap protein sources is one of the sought-after research issue that has gained significant momentum in the last couple of decades. Both PBM and BSF have all the ideal properties to be used as a substitute for FM (Rimoldi et al., 2018; Zhou et al., 2018). To date, several trials have been conducted to analyze 
313 the effect of dietary PBM and BSF on the growth performance of aquatic species but yet no

314 research reported the impact on gut microbial structure and cytokine gene expression patterns of

315 commercially important species including crayfish (Badillo, Herzka \& Viana, 2014; Gajardo et

316 al., 2017; Zhou et al., 2018). Therefore, the information obtained from this study on the effects of

317 PBM and BSF supplemented diets on gut microbiota and intestine tissue genes will add novel

318 findings that will have a vital contribution to our existing knowledge.

319 The present study found no significant impacts $(\mathrm{P}>0.05)$ of other three diets $(\mathrm{PBM}, \mathrm{FM}+\mathrm{BSF}$ and

320 PBM+BSF) on growth parameters of marron, compared to FM. A feeding trial with different

321 concentration of BSF supplemented diet on Jian carp (Cyprinus carpio var. Jian) showed a similar

322 results where the growth rate was independent of BSF supplementation (Zhou et al., 2018). As the

323 life cycle of marron under farming conditions is longer than other decapods (Lawrence, 2007), and

324 the present experiment lasted for only two months, hence, no significant growth rate was noticed.

325 There was no significant change in the health indices between FM and PBM fed marron in this

326 study, but the BSF supplemented diets resulted in significant $(\mathrm{P}<0.05)$ positive effects on $\mathrm{HO}$,

327 serum lysozyme, protein and $\mathrm{THC}$, and the impact was more pronounced $(\mathrm{P}<0.005)$ with

328 PBM+BSF diet. BSF larvae contains high percentages of protein $(\geq 40 \%)$, and inclusion of BSF in

329 the diet reported to increase the protein concentration of fish and poultry (Wang \& Shelomi, 2017).

330 We found positive impacts of BSF on the percentage of protein in the tail muscle, may be BSF has

331 improved protein assimilation efficiency in marron, however this cannot be compared with any

332 existing publication. In fish and crayfish, very limited data are currently available for the effects

333 of BSF on the immune response of the host species. A study on boiler chicken had a significant

334 increase in serum lysozyme and other immune parameters including T-lymphocyte, cell 
335 proliferation, and disease resistance after 56 days of feeding on BSF supplemented diet (Lee et al., 336 2018).

337 The gut microbiota of freshwater fish is dominated by Proteobacteria, Firmicutes, Bacteroidetes, 338 Actinobacteria, and Fusobacteria (Huang et al., 2014; Michl et al., 2017). The Proteobacteria in 339 addition with Firmicutes and Bacteroidetes comprises 90\% of bacteria in the fish gut (Ghanbari, 340 Kneifel \& Domig, 2015). Like human, the majority of beneficial bacterial species are from 341 Firmicutes and Bacteroidetes in fish (Rajilić-Stojanović, Smidt \& De Vos, 2007; Egerton et al., 342 2018). Firmicutes and Bacteroidetes possess the ability to improve the digestibility and immune 343 status of fish to counteract the effects of pathogenic bacteria (Costantini et al., 2017). Dietary 344 supplementation of protein sources, poultry and soybean meal reported to have significant effects 345 on the modulation of gut microbiota in fish (Zarkasi et al., 2016; Miao et al., 2018). In the present study, the BSF supplemented diets showed to have significant effects on the bacterial diversity of marron distal gut. Besides Proteobacteria, the results showed the abundance of Fusobacteria and Terericutes in FM and FM+BSF fed marron while Firmicutes was dominant in PBM+BSF marron. The 16S rRNA sequence data of $H$. illucens larvae gut showed to have higher percentage of Bacteroidetes ( $\geq 50 \%)$, Proteobacteria ( $\geq 25 \%)$, and Firmicutes ( $\geq 15 \%)$ (Bruno et al., 2019). Dietary protein sources can have positive effects on gut microbiota of fish where Firmicutes, Bacteroidetes, and Teniricutes are positively correlated with growth and immune parameters of fish (Egerton et al., 2018; Mekuchi et al., 2018; Miao et al., 2018). In addition, these bacterial 354 groups also have an influential role to colonize the beneficial bacteria in the fish gut (Borrelli et al., 2016; Vargas-Albores et al., 2017; Wang et al., 2018). The results of the current study found Firmicutes, Teniricutes, and Bacteroidetes richness in BSF supplemented diets that possibly come 357 from the H. illucens larvae and associated with higher growth and immunity of marron. At genus 
358 level, all four diets triggered the relative abundance of four different genera, Hynocyclicus (FM),

359 Aeromonas (PBM), Candidatus Bacilloplasma (FM+BSF), and Streptococcus (PBM+BSF).

360 Hypnocyclicus commonly found in the ocean but its role in fish and crayfish gut has yet to be

361 revealed (Roalkvam et al., 2015). Aeromonas abundance has been reported for freshwater fish and

362 some of Aeromonas hydrophila, A. veronii, A, sobria, and A, salmonicida have a potential

363 association with fish diseases (Foysal et al., 2019a; Wang et al., 2018). Candidatus Bacilloplasma

364 identified in large scale from all crustacean species including shrimp, lobster, Chinese Mitten Crab

365 (Eriocheir sinensis), a hepatopancreatic symbiont helps isopods to survive in nutrient stress,

366 promotes digestion process and up-regulated the expression of immune genes (Kostanjsek, Strus

367 \& Avgustin, 2007; Meziti et al., 2010; Chen et al., 2015, 2017; Dong et al., 2018). The present

368 study found enrichment of lactic acid bacteria (LAB) in the BSF supplemented marron, especially

369 in PBM+BSF more than 50\% of bacteria were recorded from genus Streptococcus, Lactovum, and

370 Lactobacillus. LAB are promising probiotic candidates in aquaculture whose health benefits have

371 been widely validated (Ringø \& Francois-Joel, 1998; Balcázar et al., 2008; Ringø et al., 2018).

372 To analyze the indicator microbial lineages, we applied Linear Discriminant Analysis Effect Size

373 (LEfSe), a tool that can effectively predict high-dimensional biomarkers in different conditions

374 from 16S rRNA sequence data. This tool can precisely provide biological class explanation to 375 define statistical effects, biological consistency, and effect size estimation of the classified

376 biomarkers (Huang \& Jiang, 2016). With the aid of 16S rRNA data, we identified diverse bacterial

377 lineages in three different feeding regimes where no biomarker was identified for FM+BSF fed

378 marron. Sixteen out of 21 indicator bacterial lineages from the PBM+BSF fed group indicate the

379 enrichment of bacterial population from the selected genus. Besides LAB, Bacteroides, 380 Aquabacterium and Actinobacteria were also found to be improved with PBM+BSF supplemented 
381 diet. Bacteroides abundance in fish and human gut have been described widely while a lower level

382 of Bacteroides reported to have a strong correlation in the progression of several diseases in human

383 (Zhou \& Zhi, 2016; Egerton et al., 2018; Wang et al., 2018). The genus Aquabacterium has been

384 identified from water and insect (walking sticks, Phasmatodea) gut, however, the exact role of this

385 bacteria is yet to be decoded (Kalmbach et al., 1999; Lin et al., 2009; Shelomi et al., 2013). A

386 study demonstrated the inhibitory role of Actinobacteria in the fish gut against nine common fish

387 pathogenic bacteria (Jami et al., 2015). The genus Hafnia reported from healthy crayfish, Astacus

388 astacus (L.) showed to have an association with haemorrhagic disease of brown trout (Salmo

389 trutta) (Orozova et al., 2014). In addition to significantly enriched energy metabolism pathway in

390 all four dietary groups, the PBM+BSF diet also enhanced the antibiotic and amino acid

391 biosynthesis pathways. Limited resources are currently available on the metabolic capabilities of

392 different feeds in the fish gut. However, a study by Wang et al., (2017), found increased protein

393 concentration in the diet had a positive influence on carbohydrate, protein and energy metabolism.

394 Contrarily, antibiotics provide a frontline defense mechanism against the pathogen, investigated

395 to have beneficial function raised from dietary pectin and inulin supplementation (Johnson et al.,

396 2015). The PBM+BSF diet, thus, had a positive impact on pathways associated with amino acid

397 biosynthesis, carbohydrate and energy metabolism, driven by bacteria from Firmicutes and

398 Streptococcus, as previously reported (Atasoglu et al., 1998; Besten et al., 2013; Dai et al., 2014;

399 Bhute et al., 2017).

400 The immune response of crayfish is primarily generated from the immunocompetent cells and 401 mucus of intestinal mucosal membrane (Lieschke \& Trede, 2009; Ángeles Esteban, 2012). Among 402 the factors, interleukin (IL), interferon (IF), tumour necrosis factor (TNF) are the major cytokine 403 candidates associated with immunity and inflammation of crayfish (Goins, 2003; Araki et al., 
404 2004; Jiang et al., 2015b; Calderón-Rosete et al., 2018). The present study revealed significant $405(\mathrm{P}<0.05)$ up-regulation of pro-inflammatory cytokine genes (IL-1 $\beta$, IL-17F, and TNF- $\alpha)$ in BSF 406 supplemented diet groups while similar expression patterns were observed for FM and PBM fed 407 groups. To counteract the adverse effect of overexpressed pro-inflammatory cytokines on 408 intestinal tissues, anti-inflammatory cytokines (IL-10) also need to be up-regulated to neutralize 409 inflammation (Miao et al., 2018). Enrichment of Fimicutes with dietary protein supplementation 410 reported to have a positive role on cytokine gene expression resulting into the improvement of the 411 immune status of fish (Panigrahi et al., 2007; Selim \& Reda, 2015; Miao et al., 2018). The bacteria 412 from Firmicutes phylum was found to be abundant in PBM+BSF followed by FM+BSF diet 413 groups, and thus we discovered a link between the expression level of cytokine genes and richness 414 of Firmicutes. The improved expression level of cytokine genes was recorded with dietary soybean 415 meal where phylum Firmicutes, especially Bacillus and Lactobacillus reported to be increased 416 (Miao et al., 2018). Lactic acid bacteria (LAB) associated with the production of pro and anti417 inflammatory cytokines, IL-1 $\beta$, IL-6, IL-8, TNF- $\alpha$, and IL-10 in the intestine tissue have been 418 reported (Ringø et al., 2018). The results of the present study showed a significant up-regulation 419 of intestinal cytokine genes of marron after 60 days of feeding trial in the BSF supplemented 420 groups. The higher abundance $(>50 \%)$ of Firmicutes and LAB in PBM+BSF fed marron might be 421 associated with overexpression of cytokine genes.

\section{CONCLUSION}

423 The overall findings of present study showed that the dietary supplementation of BSF significantly 424 improved the intestinal microbiota, health and immune status of marron. However, compared to 425 other three diets, significant effects of $\mathrm{PBM}+\mathrm{BSF}$ were recorded for gut microbiota and cytokine 
426 genes. However, the interaction mechanism of BSF supplemented diets with bacterial abundance

427 in the gut and associated factors needs to be further investigated.

\section{REFERENCES}

429

430

431

432

433

434

435

Albanese D, Fontana P, De Filippo C, Cavalieri D, Donati C. 2015. MICCA: A complete and accurate software for taxonomic profiling of metagenomic data. Scientific Reports 5:1-7. DOI: $10.1038 /$ srep09743.

Ambas I, Buller N, Fotedar R. 2015. Isolation and screening of probiotic candidates from marron, Cherax cainii (Austin, 2002) gastrointestinal tract (GIT) and commercial probiotic products for the use in marron culture. Journal of Fish Diseases 38:467-476. DOI: $10.1111 /$ jfd.12257.

Ambas I, Fotedar R. 2015. Survival and immunity of marron Cherax cainii (Austin, 2002) fed Bacillus mycoides supplemented diet under simulated transport. Journal of Aquaculture Research \& Development 7:1-6. DOI: 10.4172/2155-9546.1000390.

Ambas I, Fotedar R, Buller N. 2017. Synbiotic effect of Bacillus mycoides and organic selenium on immunity and growth of marron, Cherax cainii (Austin, 2002). Aquaculture Research 48:2729-2740. DOI: 10.1111/are.13105.

Ambas I, Suriawan A, Fotedar R. 2013. Immunological responses of customised probiotics-fed marron, Cherax tenuimanus, (Smith 1912) when challenged with Vibrio mimicus. Fish \& Shellfish Immunology 35:262-270. DOI: http://dx.doi.org/10.1016/j.fsi.2013.04.026.

Andrews S. 2010. FastQC: a quality control tool for high throughput sequence data. :2010. DOI: citeulike-article-id:11583827. 
447 Ángeles Esteban M. 2012. An overview of the immunological defenses in fish skin. ISRN 448 Immunology 2012:1-29. DOI: 10.5402/2012/853470.

449

450

451

452

453

454

455

456

457

458

459

460

461

462

463

464

465

466

467

468

Anuta JD, Buentello A, Patnaik S, Lawrence AL, Mustafa A, Hume ME, Gatlin DM, Kemp MC. 2011. Effect of dietary supplementation of acidic calcium sulfate (Vitoxal) on growth, survival, immune response and gut microbiota of the Pacific white shrimp, Litopenaeus vannamei. Journal of the World Aquaculture Society 42:834-844. DOI: 10.1111/j.17497345.2011.00519.x.

Araki M, Schuppe H, Fujimoto S, Nagayama T, Newland PL. 2004. Nitric oxide modulates local reflexes of the tailfan of the crayfish. Journal of Neurobiology 60:176-186. DOI: 10.1002/neu.20007.

Association of Official Agricultural Chemists (AOAC) AOAC official methods. 18th Edition Association of Official Analytical Chemists, Incorporated; Arlington: 2006 2006. $A O A C$.

Atasoglu C, Valdes C, Walker ND, Newbold CJ, Wallace RJ. 1998. De novo synthesis of amino acids by the ruminal bacteria Prevotella bryantii B14, Selenomonas ruminantium HD4, and Streptococcus bovis ES1. Applied and Environmental Microbiology 64:2836-2843.

Badillo D, Herzka SZ, Viana MT. 2014. Protein retention assessment of four levels of poultry by-product substitution of fishmeal in rainbow trout (Oncorhynchus mykiss) diets using stable isotopes of nitrogen $(\delta 15 \mathrm{~N})$ as natural tracers. PLoS ONE 9:1-8. DOI: 10.1371/journal.pone.0107523.

Balcázar JL, Vendrell D, de Blas I, Ruiz-Zarzuela I, Muzquiz JL, Girones O. 2008. Characterization of probiotic properties of lactic acid bacteria isolated from intestinal microbiota of fish. Aquaculture 278:188-191. DOI: 10.1016/j.aquaculture.2008.03.014. 
469 Benito-Martin A, Peinado H. 2015. FunRich proteomics software analysis, let the fun begin! $470 \quad$ Proteomics 15:2555-2556. DOI: 10.1002/pmic.201500260.

471 Besten G, Eumen K, Groen AK, Venema K, Reijngoud D-J, Bakker BM. 2013. The role of

472

473

474

475

476

477

478

479

480

481

482

483

484

485

486

487

488

489

490 short-chain fatty acids in the interplay between diet, gut microbiota, and host energy metabolism. Journal of Lipid Research 54:2325-2340. DOI: 10.1194/jlr.R036012.

Bhute SS, Suryavanshi MV, Joshi SM, Yajnik CS, Shouche YS, Ghaskadbi SS. 2017. Gut microbial diversity assessment of Indian type-2-diabetics reveals alterations in eubacteria, archaea, and eukaryotes. Frontiers in Microbiology 8:1-15. DOI: 10.3389/fmicb.2017.00214.

Borrelli L, Aceto S, Agnisola C, De Paolo S, Dipineto L, Stilling RM, Dinan TG, Cryan JF, Menna LF, Fioretti A. 2016. Probiotic modulation of the microbiota-gut-brain axis and behaviour in zebrafish. Scientific Reports 6:1-9. DOI: 10.1038/srep30046.

Bransden MP, Carter CG, Nowak BF. 2001. Effects of dietary protein source on growth, immune function, blood chemistry and disease resistance of Atlantic salmon (Salmo salar L.) parr. Animal Science 73:105-113. DOI: 10.1017/S1357729800058100.

Bruno D, Bonelli M, Filippis FD, Casartelli M, Ercolini D, Caccia S. 2019. The intestinal microbiota of Hermetia illucens larvae is affected by diet and shows a diverse composition in the different midgut regions. Applied and Environmental Microbiology 85:1-14. DOI: 10.1128/AEM.01864-18.

Calderón-Rosete G, González-Barrios J, Lara-Lozano M, Piña-Leyva C, Rodríguez-Sosa L. 2018. Transcriptional identification of related proteins in the immune system of the crayfish Procambarus clarkii. High-Throughput 7:26. DOI: 10.3390/ht7030026. 
491

492

493

494

495

496

497

498

499

500

501

502

503

504

505

506

507

508

509

510

511

Cashion T, Manach FL, Zeller D, Pauly D. 2017. Most fish destined for fishmeal production are food- grade fish. Fish and Fisheries 2017:1-8. DOI: 10.1111/faf.12209.

Chen X, Di P, Wang H, Li B, Pan Y, Yan S, Wang Y. 2015. Bacterial community associated with the intestinal tract of Chinese mitten crab (Eriocheir sinensis) farmed in Lake Tai, China. PLoS ONE 10:1-21. DOI: 10.1371/journal.pone.0123990.

Chen W, Ng TH, Wu J, Chen J, Wang H. 2017. Microbiome dynamics in a shrimp grow-out pond with possible outbreak of acute hepatopancreatic necrosis disease. Scientific Reports 7:1-12. DOI: 10.1038/s41598-017-09923-6.

Costantini L, Molinari R, Farinon B, Merendino N. 2017. Impact of omega-3 fatty acids on the gut microbiota. International Journal of Molecular Sciences 18:1-18. DOI: $10.3390 /$ ijms 18122645 .

Dai Z, Wu Z, Hang S, Zhu W, Wu G. 2014. Amino acid metabolism in intestinal bacteria and its potential implications for mammalian reproduction. Molecular Human Reproduction 21:389-409. DOI: 10.1093/molehr/gav003.

DoF. 2010. The marron fishery. Department of Fisheries, Government of Western Australia:1-8.

Dong J, Li X, Zhang R, Zhao Y, Wu G, Liu J, Zhu X, Li L. 2018. Comparative analysis of the intestinal bacterial community and expression of gut immunity genes in the Chinese Mitten Crab (Eriocheir sinensis). AMB Express 8:1-12. DOI: 10.1186/s13568-018-0722-0.

Dozier WA, Dale NM, Dove CR. 2003. Nutrient compostion of feed-grade and pet-food-grade poultry by-product meal. Journal of Applied Poultry Research 12:526-530. DOI: 10.1093/japr/12.4.526. 
512 Egerton S, Culloty S, Whooley J, Stanton C, Ross RP. 2018. The gut microbiota of marine fish.

513 Frontiers in Microbiology 9:1-17. DOI: 10.3389/fmicb.2018.00873.

514 Emre Y, Sevgili H, Diler I. 2004. Replacing fish meal with poultry by-product meal in practical 515 diets for mirror carp (Cyprinus carpio) fingerlings. Turkish Journal of Fisheries and Aquatic $516 \quad$ Sciences 3:81-85. DOI: 10.1016/j.aquaculture.2007.04.084.

517 Falcinelli S, Picchietti S, Rodiles A, Cossignani L, Merrifield DL, Taddei AR, Maradonna F,

518 Olivotto I, Gioacchini G, Carnevali O. 2015. Lactobacillus rhamnosus lowers zebrafish 519 lipid content by changing gut microbiota and host transcription of genes involved in lipid 520 metabolism. Scientific Reports 5:8-10. DOI: 10.1038/srep09336.

521

522

523

524

525

526

527

528

529

530

531

532

533

Foysal MJ, Momtaz F, Ali MH, Siddik MAB, Chaklader MR, Rahman MM, Prodhan MSH, Cole AJ. 2019a. Molecular characterization and interactome analysis of aerolysin (aer) gene from fish pathogen Aeromonas veronii: The pathogenicity inferred from sequence divergence and linked to histidine kinase (che A). Journal of Fish Diseases 42:465-475. DOI: $10.1111 /$ jfd.12954.

Foysal MJ, Fotedar R, Gupta SK, Chaklader MR. 2019b. Biological ball filters regulate bacterial communities in marron (Cherax cainii) culture system. Letters in Applied Microbiology:in press. DOI: 10.1111/lam.13125.

Fuertes JB, Celada JD, Carral JM, Sáez-Royuela M, González-Rodríguez Á. 2013. Replacement of fish meal with poultry by-product meal in practical diets for juvenile crayfish (Pacifastacus leniusculus Dana, Astacidae) from the onset of exogenous feeding. Aquaculture 404-405:22-27. DOI: 10.1016/j.aquaculture.2013.04.019.

Gajardo K, Jaramillo-Torres A, Kortner TM, Merrifield DL, Tinsley J, Bakke AM, 
534

535

536

537

538

539

540

541

542

543

544

545

546

547

548

549

550

551

552

553

554

Krogdahl Å. 2017. Alternative protein sources in the diet modulate microbiota and functionality in the distal intestine of Atlantic salmon (Salmo salar). Applied and Environmental Microbiology 83:1-16. DOI: 10.1128/AEM.02615-16.

Ghanbari M, Kneifel W, Domig KJ. 2015. A new view of the fish gut microbiome: Advances from next-generation sequencing. Aquaculture 448:464-475. DOI: 10.1016/j.aquaculture.2015.06.033.

Goins KR. 2003. Host defense mechanisms in the crayfish: The effect of injection with live or killed bacteria. Electronic Theses and Dissertations Paper 757:http://dc.estu.edu/etd/757.

Hammer Ø, Harper DAT, Ryan PD. 2009. PAST-Palaeontological statistics. Palaeontologia Electronica 4:1-9.

Huang W, Jiang X. 2016. Profiling of sediment microbial community in dongting lake before and after impoundment of the three gorges dam. International Journal of Environmental Research and Public Health 13:1-15. DOI: 10.3390/ijerph13060617.

Huang Z, Li X, Wang L, Shao Z. 2014. Changes in the intestinal bacterial community during the growth of white shrimp, Litopenaeus vannamei. Aquaculture Research:1-10. DOI: 10.1111/are.12628.

Iwai S, Weinmaier T, Schmidt BL, Albertson DG, Poloso NJ, Dabbagh K, DeSantis TZ. 2016. Piphillin: Improved prediction of metagenomic content by direct inference from human microbiomes. PLoS ONE 11:1-18. DOI: 10.1371/journal.pone.0166104.

Jami M, Ghanbari M, Kneifel W, Domig KJ. 2015. Phylogenetic diversity and biological activity of culturable Actinobacteria isolated from freshwater fish gut microbiota. 
Microbiological Research 175:6-15. DOI: 10.1016/j.micres.2015.01.009.

556

557

558

559

560

561

562

563

564

565

566

567

568

569

570

571

572

573

574

575

576

Jiang WD, Hu K, Zhang JX, Liu Y, Jiang J, Wu P, Zhao J, Kuang SY, Tang L, Tang WN, Zhang YA, Zhou XQ, Feng L. 2015a. Soyabean glycinin depresses intestinal growth and function in juvenile Jian carp (Cyprinus carpio var Jian): Protective effects of glutamine. British Journal of Nutrition 114:1569-1583. DOI: 10.1017/S0007114515003219.

Jiang H, Qian Z, Lu W, Ding H, Yu H, Wang H, Li J. 2015b. Identification and characterization of reference genes for normalizing expression data from red swamp crawfish Procambarus clarkii. International Journal of Molecular Sciences 16:21591-21605. DOI: 10.3390/ijms160921591.

Jim F, Garamumhango P, Musara C. 2017. Comparative analysis of nutritional value of Oreochromis niloticus (Linnaeus), Nile tilapia, meat from three different ecosystems. Journal of Food Quality 2017:ID 674347. DOI: 10.1155/2017/6714347.

Johnson LP, Walton GE, Psichas A, Frost GS, Gibson GR, Barraclough TG. 2015. Prebiotics modulate the effects of antibiotics on gut microbial diversity and functioning in vitro. Nutrients 7:4480-4497. DOI: 10.3390/nu7064480.

Joshi N, Fass J. 2011. sickle - A windowed adaptive trimming tool for FASTQ files using quality. (Version 1.33):[Software].

Kalmbach S, Manz W, Wecke J, Szewzyk U. 1999. Aquabacterium gen. nov., with description of Aquabacterium citratiphilum sp. nov., Aquabacterium parvum sp. nov. and Aquabacterium commune sp. nov., three in situ dominant bacterial species from the Berlin drinking water system. International Journal of Systematic Bacteriology 49:769-777. DOI: 10.1099/00207713-49-2-769. 
577 Kostanjsek R, Strus J, Avgustin G. 2007. “ Candidatus Bacilloplasma ," a novel lineage of 578 Mollicutes associated with the hindgut wall of the terrestrial isopod Porcellio scaber 579 (Crustacea: Isopoda). Applied and Environmental Microbiology 73:5566-5573. DOI: 580

581

582

583

584

585

586

587

588

589

590

591

592

593

594

595

596

597

598

Kroeckel S, Harjes AGE, Roth I, Katz H, Wuertz S, Susenbeth A, Schulz C. 2012. When a turbot catches a fly: Evaluation of a pre-pupae meal of the Black Soldier Fly (Hermetia illucens) as fish meal substitute - Growth performance and chitin degradation in juvenile turbot (Psetta maxima). Aquaculture 364-365:345-352. DOI: 10.1016/j.aquaculture.2012.08.041.

Lawrence C. 2007. Improved performance of marron using genetic and pond management strategies. Fisheries Research Contract Report 17:1-178.

Lee J, Kim Y-M, Park Y-K, Yang Y-C, Jung B-G, Lee B-J. 2018. Black soldier fly (Hermetia illucens) larvae enhances immune activities and increases survivability of broiler chicks against experimental infection of Salmonella gallinarum. Journal of Veterinary Medical Science 80:736-740. DOI: 10.1292/jvms.17-0236.

Lieschke GJ, Trede NS. 2009. Fish immunology. Current Biology 19:678-682. DOI: 10.1016/j.cub.2009.06.068.

Lin MC, Jiang SR, Chou JH, Arun AB, Young CC, Chen WM. 2009. Aquabacterium fontiphilum sp. nov., isolated from spring water. International Journal of Systematic and Evolutionary Microbiology 59:681-685. DOI: 10.1099/ijs.0.000745-0.

Mai HV, Fotedar R. 2018. Haemolymph constituents and osmolality as functions of moult stage, body weight, and feeding status in marron, Cherax cainii (Austin and Ryan, 2002) and 

yabbies, Cherax destructor (Clark, 1936). Saudi Journal of Biological Sciences 25:689-696. DOI: $10.1016 /$ j.sjbs.2016.03.007.

601

602

603

604

605

606

607

608

609

610

611

612

613

614

615

616

617

618

619

620

Mekuchi M, Asakura T, Sakata K, Yamaguchi T, Teruya K, Kikuchi J. 2018. Intestinal microbiota composition is altered according to nutritional biorhythms in the leopard coral grouper (Plectropomus leopardus). PLoS ONE 13:1-16. DOI: 10.1371/journal.pone.0197256.

Meziti A, Ramette A, Mente E, Kormas KA. 2010. Temporal shifts of the Norway lobster (Nephrops norvegicus) gutbacterial communities. FEMS Microbiology Ecology 74:472-484. DOI: $10.1111 / \mathrm{j} .1574-6941.2010 .00964 . x$.

Miao S, Zhao C, Zhu J, Hu J, Dong X, Sun L. 2018. Dietary soybean meal affects intestinal homoeostasis by altering the microbiota, morphology and inflammatory cytokine gene expression in northern snakehead. Scientific Reports 8:1-10. DOI: 10.1038/s41598-01718430-7.

Michl SC, Ratten J-M, Beyer M, Hasler M, LaRoche J, Schulz C. 2017. The malleable gut microbiome of juvenile rainbow trout (Oncorhynchus mykiss): Diet-dependent shifts of bacterial community structures. Plos One 12:e177735. DOI: 10.1371/journal.pone.0177735.

Militon C, Boucher D, Vachelard C, Perchet G, Barra V, Troquet J, Peyretaillade E, Peyret P. 2010. Bacterial community changes during bioremediation of aliphatic hydrocarboncontaminated soil. FEMS Microbiology Ecology 74:669-681. DOI: 10.1111/j.15746941.2010.00982.x.

Mirarab S, Nguyen N, Guo S, Wang L-S, Kim J, Warnow T. 2015. PASTA: Ultra-large multiple sequence alignment for nucleotide and amino-acid sequences. Journal of 
622

623

624

625

626

627

628

629

630

631

632

633

634

635

636

637

638

639

640

641

Naylor RL, Hardy RW, Bureau DP, Chiu A, Elliott M, Farrell AP, Forster I, Gatlin DM, Goldburg RJ, Hua K, Nichols PD. 2009. Feeding aquaculture in an era of finite resources. Proceedings of the National Academy of Sciences 106:15103-15110. DOI: 10.1073/pnas.0905235106.

Oksanen AJ, Blanchet FG, Kindt R, Legen- P, Minchin PR, Hara RBO, Simpson GL, SolyP, Stevens MHH, Wagner H. 2018. Package “vegan.” :[Software].

Orozova P, Sirakov I, Chikova V, Popova R, Al-Harbi AH, Crumlish M, Austin B. 2014. Recovery of Hafnia alvei from diseased brown trout, Salmo trutta L., and healthy noble crayfish, Astacus astacus (L.), in Bulgaria. Journal of Fish Diseases 37:891-898. DOI: 10.1111/jfd.12212.

Panigrahi A, Kiron V, Satoh S, Hirono I, Kobayashi T, Sugita H, Puangkaew J, Aoki T. 2007. Immune modulation and expression of cytokine genes in rainbow trout Oncorhynchus mykiss upon probiotic feeding. Developmental and Comparative Immunology 31:372-382. DOI: 10.1016/j.dci.2006.07.004.

Parikh HI, Koparde VN, Bradley SP, Buck GA, Sheth NU. 2016. MeFiT: Merging and filtering tool for illumina paired-end reads for 16S rRNA amplicon sequencing. BMC Bioinformatics 17:1-6. DOI: 10.1186/s12859-016-1358-1.

Pauly D, Zeller D. 2017. Comments on FAOs state of world fisheries and aquaculture (SOFIA 2016). Marine Policy 77:176-181. DOI: 10.1016/j.marpol.2017.01.006.

Quast C, Pruesse E, Yilmaz P, Gerken J, Schweer T, Yarza P, Peplies J, Glöckner FO. 2013. 
642

643

644

645

646

647

648

649

650

651

652

653

654

655

656

657

658

659

660

661

662

The SILVA ribosomal RNA gene database project: Improved data processing and web-based tools. Nucleic Acids Research 41:590-596. DOI: 10.1093/nar/gks1219.

Rajilić-Stojanović M, Smidt H, De Vos WM. 2007. Diversity of the human gastrointestinal tract microbiota revisited. Environmental Microbiology 9:2125-2136. DOI: 10.1111/j.14622920.2007.01369.x.

Rimoldi S, Terova G, Ascione C, Giannico R, Brambilla F. 2018. Next generation sequencing for gut microbiome characterization in rainbow trout (Oncorhynchus mykiss) fed animal byproduct meals as an alternative to fishmeal protein sources. PLoS ONE 13:1-29. DOI: 10.1371/journal.pone.0193652.

Ringø E, Francois-Joel G. 1998. Lactic acid bacteria in fish: a review. Aquaculture 160:177-203.

Ringø E, Hoseinifar SH, Ghosh K, Doan HV, Beck BR, Song SK. 2018. Lactic acid bacteria in finfish-An update. Frontiers in Microbiology 9:1-37. DOI: 10.3389/fmicb.2018.01818.

Roalkvam I, Bredy F, Baumberger T, Pedersen RB, Steen IH. 2015. Hypnocyclicus thermotrophus gen. Nov., sp. nov. isolated from a microbial mat in a hydrothermal vent field. International Journal of Systematic and Evolutionary Microbiology 65:4521-4525. DOI: 10.1099/ijsem.0.000606.

Safari O, Paolucci M. 2018. Effect of in vitro selected synbiotics (galactooligosaccharide and mannanoligosaccharide with or without Enterococcus faecalis) on growth performance, immune responses and intestinal microbiota of juvenile narrow clawed crayfish, Astacus leptodactylus lep. Aquaculture Nutrition 24:247-259. DOI: 10.1111/anu.12553.

Sang HM, Fotedar R. 2004. Growth, survival, haemolymph osmolality and organosomatic 
663

664

665

666

667

668

669

670

671

672

673

674

675

676

677

678

679

680

681

682

683

indices of the western king prawn (Penaeus latisulcatus Kishinouye, 1896) reared at different salinities.

Aquaculture

234:601-614.

DOI:

http://dx.doi.org/10.1016/j.aquaculture.2004.01.008.

Saoud IP, Rodgers LJ, Davis DA, Rouse DB. 2008. Replacement of fish meal with poultry byproduct meal in practical diets for redclaw crayfish (Cherax quadricarinatus). Aquaculture Nutrition 14:139-142. DOI: 10.1111/j.1365-2095.2007.00513.x.

Selim KM, Reda RM. 2015. Improvement of immunity and disease resistance in the Nile tilapia, Oreochromis niloticus, by dietary supplementation with Bacillus amyloliquefaciens. Fish and Shellfish Immunology 44:496-503. DOI: 10.1016/j.fsi.2015.03.004.

Shekhar MS, Kiruthika J, Ponniah AG. 2013. Identification and expression analysis of differentially expressed genes from shrimp (Penaeus monodon) in response to low salinity stress. Fish and Shellfish Immunology 35:1957-1968. DOI: 10.1016/j.fsi.2013.09.038.

Shelomi M, Lo WS, Kimsey LS, Kuo CH. 2013. Analysis of the gut microbiota of walking sticks (Phasmatodea). BMC Research Notes 6. DOI: 10.1186/1756-0500-6-368.

Skelton J, Geyer KM, Lennon JT, Creed RP, Brown BL. 2017. Multi-scale ecological filters shape the crayfish microbiome. Symbiosis 72:159-170. DOI: 10.1007/s13199-016-0469-9.

St-Hilaire S, Sheppard C, Tomberlin JK, Irving S, Newton L, McGuire MA, Mosley EE, Hardey RW, Sealey W. 2007. Fly prepupae as a feedstuff for Rainbow Trout, Oncorhynchus mykiss. Journal of the World Aquaculture Society 38:59-67.

Stamer A, Wesselss S, Neidigk R, Hoerstgen-Schwark G. 2014. Black Soldier Fly (Hermetia illucens) larvae-meal as an example for a new feed ingredients' class in aquaculture diets. 
684

685

686

687

688

689

690

691

692

693

694

695

696

697

698

699

700

701

702

703

704

Proceedings of the 4th ISOFAR Scientific Conference:13-15. DOI: 10.1080/00927870601042134.

Stankus A. 2013. Integrating biosystems to foster sustainable aquaculture: Using black soldier fly larvae as feed in aquaponic systems. MSc Thesis Zoology Department:72. DOI: 10.1134/S0097807807040033.

Tacon AGJ, Metian M. 2008. Global overview on the use of fish meal and fish oil in industrially compounded aquafeeds: Trends and future prospects. Aquaculture 285:146-158. DOI: 10.1016/j.aquaculture.2008.08.015.

Vargas-Albores F, Porchas-Cornejo MA, Martínez-Porchas M, Villalpando-Canchola E, Gollas-Galván T, Martínez-Córdova LR. 2017. Bacterial biota of shrimp intestine is significantly modified by the use of a probiotic mixture: a high throughput sequencing approach. Helgoland Marine Research 71:1-10. DOI: 10.1186/s10152-017-0485-z.

Wang XX, Chen MY, Wang K, Ye JD. 2017. Growth and metabolic responses in Nile tilapia (Oreochromis niloticus) subjected to varied starch and protein levels of diets. Italian Journal of Animal Science 16:308-316. DOI: 10.1080/1828051X.2016.1275953.

Wang AR, Ran C, Ringø E, Zhou ZG. 2018. Progress in fish gastrointestinal microbiota research. Reviews in Aquaculture 10:626-640. DOI: 10.1111/raq.12191.

Wang Y-S, Shelomi M. 2017. Review of black soldier fly (Hermetia illucens) as animal feed and human Food. Foods 6:91. DOI: 10.3390/foods6100091.

Wu YB, Ren X, Chai XJ, Li P, Wang Y. 2018. Replacing fish meal with a blend of poultry byproduct meal and feather meal in diets for giant croaker (Nibea japonica). Aquaculture 
Nutrition 24:1085-1091. DOI: 10.1111/anu.12647.

706

707

708

709

710

711

712

713

714

715

716

717

718

719

720

721

722

723

724

725
Yang Y, Xie S, Cui Y, Zhu X, Lei W, Yang Y. 2006. Partial and total replacement of fishmeal with poultry by-product meal in diets for gibel carp, Carassius auratus gibelio Bloch. Aquaculture Research 37:40-48. DOI: 10.1111/j.1365-2109.2005.01391.x.

Zarkasi KZ, Taylor RS, Abell GCJ, Tamplin ML, Glencross BD, Bowman JP. 2016. Atlantic salmon (Salmo salar L.) gastrointestinal microbial community dynamics in relation to digesta properties and diet. Microbial Ecology 71:589-603. DOI: 10.1007/s00248-015-0728-y.

Zhou JS, Liu SS, Ji H, Yu HB. 2018. Effect of replacing dietary fish meal with black soldier fly larvae meal on growth and fatty acid composition of Jian carp (Cyprinus carpio var. Jian). Aquaculture Nutrition 24:424-433. DOI: 10.1111/anu.12574.

Zhou Y, Zhi F. 2016. Lower level of Bacteroides in the gut microbiota is associated with inflammatory bowel disease: A meta-analysis. BioMed Research International 2016:1-9. DOI: $10.1155 / 2016 / 5828959$.

Zokaeifar H, Balcázar JL, Saad CR, Kamarudin MS, Sijam K, Arshad A, Nejat N. 2012. Effects of Bacillus subtilis on the growth performance, digestive enzymes, immune gene expression and disease resistance of white shrimp, Litopenaeus vannamei. Fish and Shellfish Immunology 33:683-689. DOI: 10.1016/j.fsi.2012.05.027.

Zoqratt MZH, Eng WWH, Thai BT, Austin CM, Gan HM. 2018. Microbiome analysis of Pacific white shrimp gut and rearing water from Malaysia and Vietnam: implications for aquaculture research and management. PeerJ 6:e5826. DOI: 10.7717/peerj.5826.

PeerJ reviewing PDF | (2018:12:33367:1:1:NEW 22 Mar 2019) 


\section{Table 1 (on next page)}

Feed ingredients and proximate composition (\% dry weight) of the marron diets used in this study

*All ingredients were procured and diets were prepared by Glenn Forest Specialty Feeds, Western Australia.

Abbreviation: $\mathrm{FM}=$ Fishmeal; $\mathrm{PBM}=$ Poultry-by-product meal; FM+BSF = Fishmeal + Black soldier fly meal; $\mathrm{PBM}+\mathrm{BSF}=$ Poultry-by-product meal + Black soldier fly meal; $\mathrm{CP}=$ Crude protein; $\mathrm{GE}=$ Gross energy; $\mathrm{MJ}=$ Mega joule. 


\begin{tabular}{|c|c|c|c|c|}
\hline Ingredients* & FM & PBM & FM + BSF & $\mathrm{PBM}+\mathrm{BSF}$ \\
\hline Fishmeal & 41 & 0 & 32 & 0 \\
\hline Poultry by product meal & 0 & 39 & 0 & 31.5 \\
\hline Black soldier fly meal & 0 & 0 & 12 & 11 \\
\hline Soya bean meal & 10 & 10 & 10 & 10 \\
\hline Wheat & 37 & 38 & 36 & 36 \\
\hline Corn starch & 4.80 & 4.80 & 4 & 4.80 \\
\hline Cod liver oil & 4.20 & 5.20 & 3 & 3.70 \\
\hline $\mathrm{CaCO}_{3}$ & 0.02 & 0.02 & 0.02 & 0.02 \\
\hline Vitamin premix & 0.23 & 0.23 & 0.23 & 0.23 \\
\hline Vitamin C & 0.05 & 0.05 & 0.05 & 0.05 \\
\hline Cholesterol & 0.50 & 0.50 & 0.50 & 0.50 \\
\hline Lecithin-Soy & 1 & 1 & 1 & 1 \\
\hline Betacaine & 1.20 & 1.20 & 1.20 & 1.20 \\
\hline Total & 100 & 100 & 100 & 100 \\
\hline \multicolumn{5}{|c|}{ Proximate composition of ( $\mathrm{g} \mathrm{kg}^{-1}$ dry weight basis) } \\
\hline $\mathrm{CP} \%$ & 29.93 & 29.61 & 30.07 & 30.20 \\
\hline Lipid \% & 7.12 & 7.32 & 7.56 & 7.48 \\
\hline GE MJ kg-1 & 18.21 & 18.75 & 18.45 & 18.53 \\
\hline
\end{tabular}

1 


\section{Table 2 (on next page)}

Water quality parameters in marron tanks fed different proteins

Abbreviation: $\mathrm{DO}=$ Dissolved oxygen; FM = Fishmeal; $\mathrm{PBM}=$ Poultry-by-product meal; FM+BSF = Fishmeal + Black soldier fly meal; PBM+BSF = Poultry-by-product meal + Black soldier fly meal. 


\begin{tabular}{|c|c|c|c|c|}
\hline Parameters & FM & PBM & FM+BSF & PBM+BSF \\
\hline Temperature $\left({ }^{\circ} \mathrm{C}\right)$ & $22.3 \pm 0.014$ & $22.3 \pm 0.011$ & $22.4 \pm 0.013$ & $22.4 \pm 0.01$ \\
\hline $\mathrm{pH}$ & $7.5 \pm 0.006$ & $7.5 \pm 0.005$ & $7.5 \pm 0.005$ & $7.6 \pm 0.003$ \\
\hline $\mathrm{DO}(\mathrm{mg} / \mathrm{L})$ & $6.51 \pm 0.003$ & $6.55 \pm 0.003$ & $6.31 \pm 0.006$ & $6.65 \pm 0.002$ \\
\hline Nitrate $(\mathrm{mg} / \mathrm{L})$ & $0.049 \pm 0.001$ & $0.047 \pm 0.001$ & $0.048 \pm 0.001$ & $0.046 \pm 0.001$ \\
\hline Nitrite (mg/L) & $0.015 \pm 0.0005$ & $0.017 \pm 0.0007$ & $0.016 \pm 0.0006$ & $0.018 \pm 0.0008$ \\
\hline Ammonia (mg/L) & $0.20 \pm 0.01$ & $0.22 \pm 0.01$ & $0.21 \pm 0.01$ & $0.22 \pm 0.01$ \\
\hline
\end{tabular}

1 


\section{Table 3(on next page)}

Mean \pm SE of some health parameters of marron at the end of feeding trial

Abbreviation: FM = Fishmeal; PBM = Poultry-by-product meal; FM+BSF = Fishmeal + Black soldier fly meal; $\mathrm{PBM}+\mathrm{BSF}=$ Poultry-by-product meal + Black soldier fly meal; WG = Weight gain; SGR = Specific growth rate; $\mathrm{HI}=$ Hepatopancreas index; $\mathrm{THC}=$ Total haemocyte count; $\mathrm{HO}=$ Haemolymph osmolality.

*Significantly different at $\alpha$-level of 0.05 .

**Significantly different at $\alpha$-level of 0.005 .

† From tail muscle. "From hepatopancreas. 


\begin{tabular}{lllll}
\hline Parameters & FM & PBM & FM+BSF & PBM+BSF \\
\hline WG & $24.33 \pm 1.38$ & $23.91 \pm 0.77$ & $25.35 \pm 0.85$ & $26.49 \pm 0.84$ \\
SGR & $0.51 \pm 0.26$ & $0.49 \pm 0.12$ & $0.51 \pm 0.13$ & $0.53 \pm 0.14$ \\
Protein $\dagger$ & $82.4 \pm 0.67$ & $83.2 \pm 0.56$ & $85.4 \pm 1.01^{*}$ & $89.4 \pm 0.95^{* *}$ \\
Energy $\dagger$ & $20010.3 \pm 75.11$ & $20242.3 \pm 89.24$ & $21672.8 \pm 311.5^{*}$ & $21778.5 \pm 356.9^{*}$ \\
Fat & $8.9 \pm 0.11$ & $8.4 \pm 0.11$ & $6.4 \pm 0.50^{*}$ & $6.1 \pm 0.40^{*}$ \\
HI & $38.5 \pm 0.52$ & $36.9 \pm 0.27$ & $34.5 \pm 0.31^{*}$ & $32.2 \pm 0.72^{*}$ \\
Lysozyme & $0.42 \pm 0.006$ & $0.4 \pm 0.003$ & $0.47 \pm 0.011^{*}$ & $0.59 \pm 0.036^{* *}$ \\
THC & $8.0 \pm 0.09$ & $7.9 \pm 0.09$ & $8.2 \pm 0.13^{*}$ & $9.5 \pm 0.15^{* *}$ \\
HO & $0.4 \pm 0.003$ & $0.41 \pm 0.005$ & $0.42 \pm 0.011$ & $0.46 \pm 0.010^{* *}$ \\
\hline
\end{tabular}

1 


\section{Table 4 (on next page)}

Major diversity indices (Mean $\pm \mathrm{SE}$ ) of bacterial genera in marron gut at the end of feeding trial

Abbreviation: FM = Fishmeal; $\mathrm{PBM}=$ Poultry-by-product meal; FM+BSF $=$ Fishmeal + Black soldier fly meal; PBM+BSF = Poultry-by-product meal + Black soldier fly meal. *Significantly different at $\alpha$-level of 0.05 . **Significantly different at $\alpha$-level of 0.005 . ***Significantly different at $\alpha$-level of 0.001 . 


\begin{tabular}{ccccc}
\hline Treatment & Shannon & Simpson & Fisher & Chao1 \\
& $(\mathrm{SE})$ & $(\mathrm{SE})$ & alpha $(\mathrm{SE})$ & $\mathbf{( S E )}$ \\
\hline FM & $1.51(0.13)$ & $0.69(0.03)$ & $7.59(1.36)$ & $86.74(10.33)$ \\
PBM & $1.77(0.36)$ & $0.69(0.07)$ & $11.34(1.30)$ & $116.68(4.6)^{*}$ \\
FM+BSF & $1.89(0.27)$ & $0.76(0.04)$ & $12.3(1.28)^{*}$ & $103.99(3.08)$ \\
PBM+BSF & $3.19(0.06)^{* * *}$ & $0.82(0.006)^{* *}$ & $16.7(1.91)^{*}$ & $128.48(6.2)^{*}$
\end{tabular}

1 


\section{Figure 1}

Effects of four different dietary protein on marron distal gut. (A)Non-metric multidimensional scaling (nMDS) plot showing feeding effects on microbiota of distal gut in marron. (B) Number of shared and unique genera in four different protein fed groups.

Abbreviation: FM = Fishmeal; PBM = Poultry-by-product meal; FM+BSF = Fishmeal + Black soldier fly meal; PBM+BSF = Poultry-by-product meal + Black soldier fly meal.

A

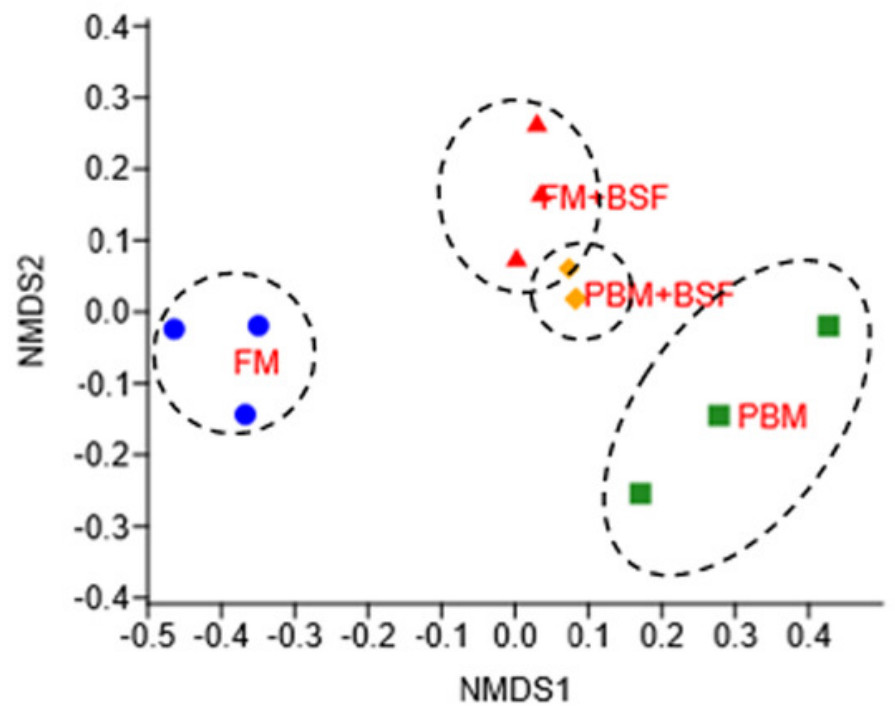

B

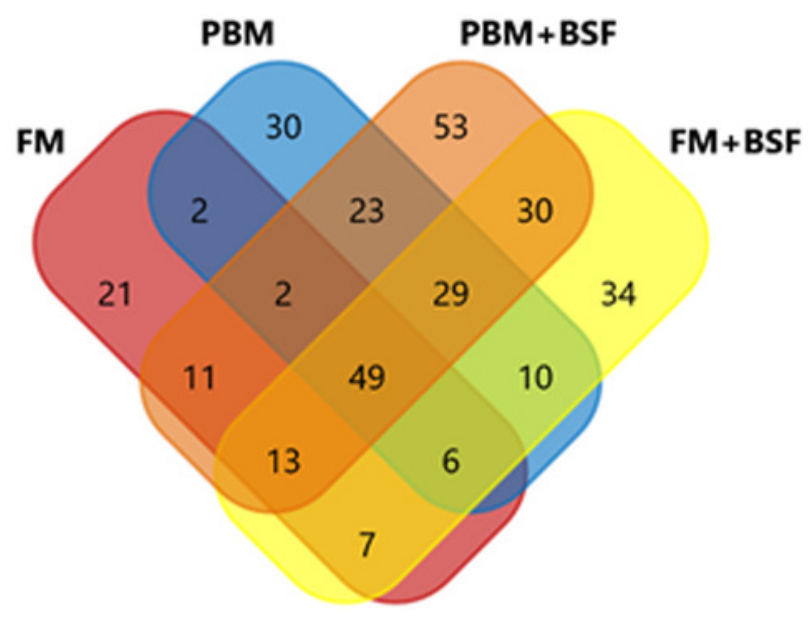


Figure 2

(A) Relative abundance of bacterial OTUs at phylum level. (B) Relative abundance of bacterial OTUs at a genus level.

Abbreviation: FM = Fishmeal; PBM = Poultry-by-product meal; FM+BSF $=$ Fishmeal + Black soldier fly meal; PBM+BSF = Poultry-by-product meal + Black soldier fly meal. 
A

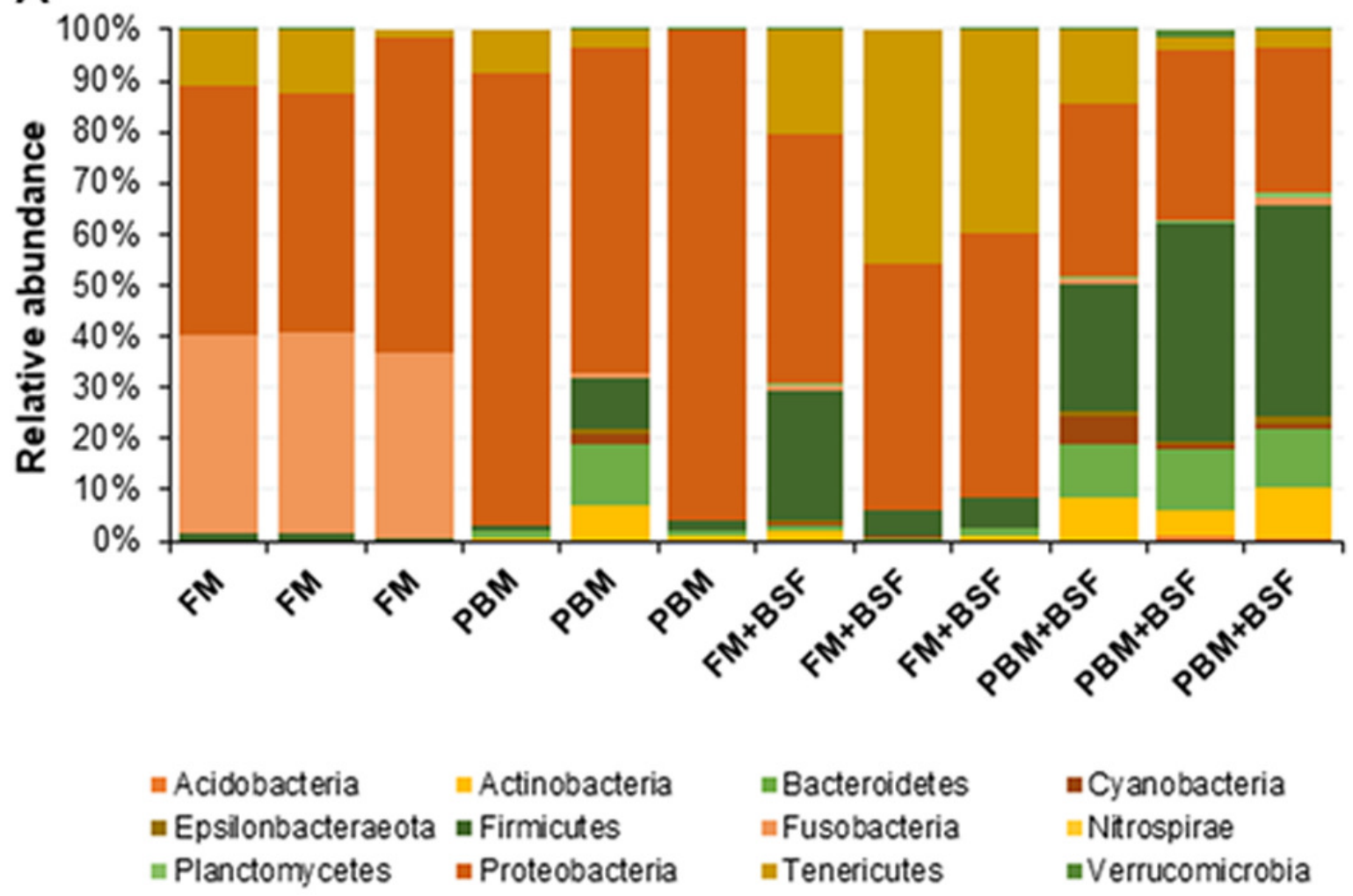

B

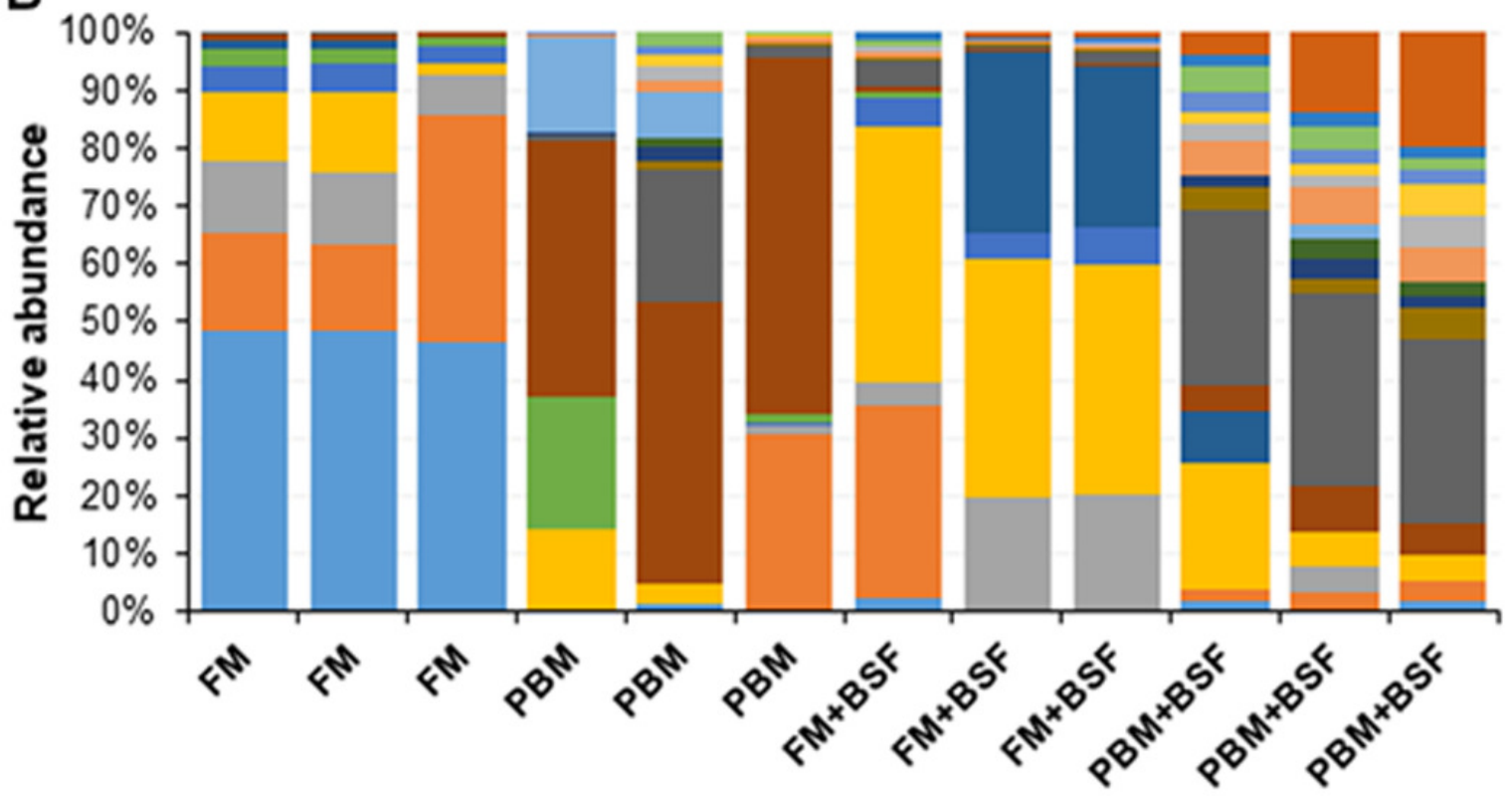

= Hypnocyclicus

= Candidatus Bacilloplasma

- Candidatus Hepatoplasma

- Polynucleobacter

= Shewanella

= Porphyromonas

a Rhodobacter
= Vibrio

- Serratia

- Aeromonas

- Limnohabitans

= Corynebacterium

= hocl clade

- Lactovum
= Hafnia-Obesumbacterium

=Enterobacter

- Streptococcus

- Flavobacterium

=Ezakiella

=Anaerococcus 


\section{Figure 3}

Indicator bacteria at genus level in three different proteins fed marron groups.

FM+BSF had no significant indicator at LDA cut-off value of 8.0.

Abbreviation: FM = Fishmeal; PBM = Poultry-by-product meal; FM+BSF = Fishmeal + Black soldier fly meal; $\mathrm{PBM}+\mathrm{BSF}=$ Poultry-by-product meal + Black soldier fly meal.

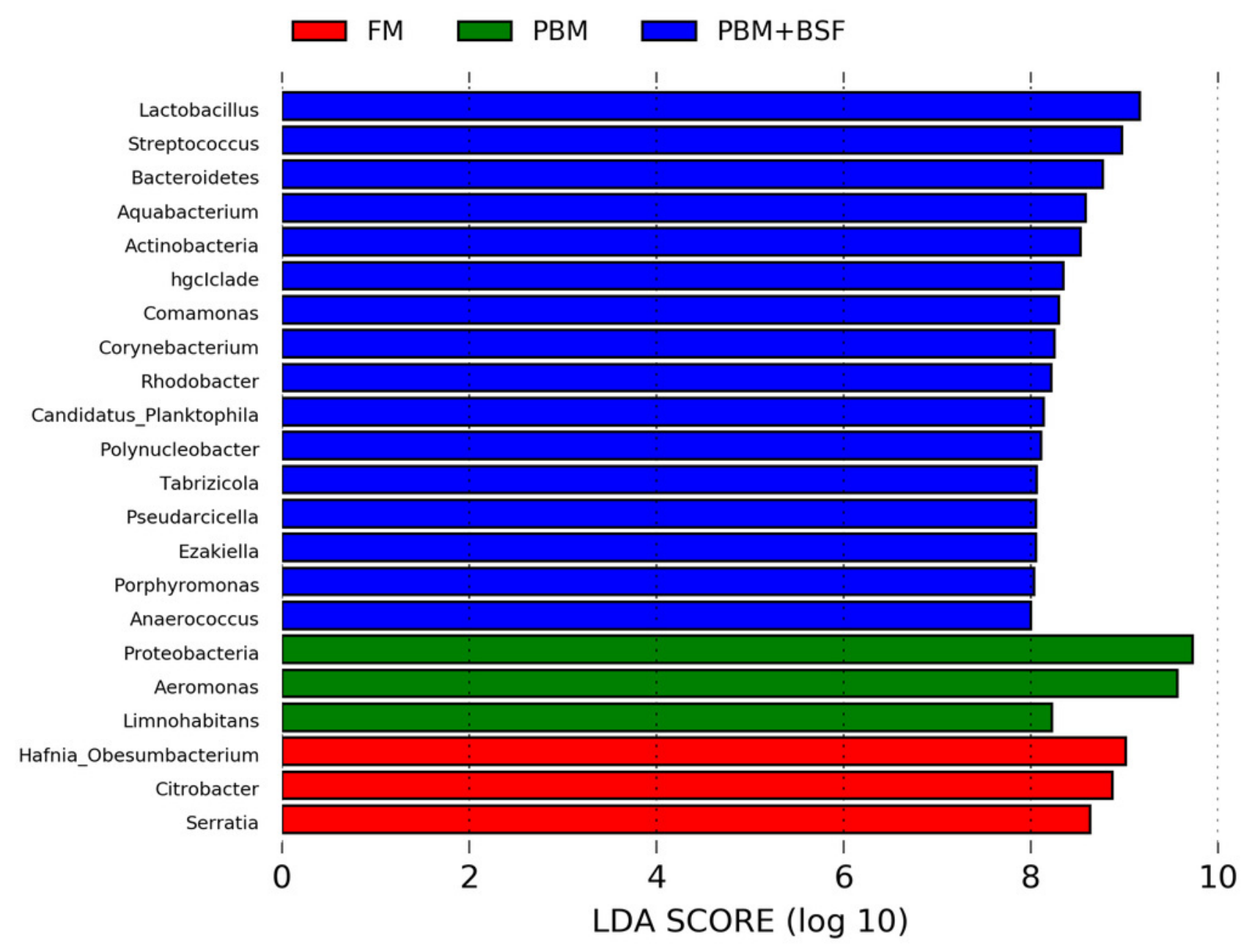




\section{Figure 4}

Circular LEfSe cladogram representing the phylogenetic distribution of bacterial lineage in three different proteins fed marron groups.

The lineage with LDA scores of 3.0 or above are displayed here. The red, green and blue colour indicate FM, PBM, and PBM+BSF, respectively. The dot at centre represents the OTUs at phylum level while the outer circle of dots denotes OTUs at genus level. The order, family, and genus that are significantly different between two groups are given in the upper right corner with respective colour codes.

Abbreviation: FM = Fishmeal; PBM = Poultry-by-product meal; FM+BSF = Fishmeal + Black soldier fly meal; $\mathrm{PBM}+\mathrm{BSF}=$ Poultry-by-product meal + Black soldier fly meal.

\section{Cladogram}
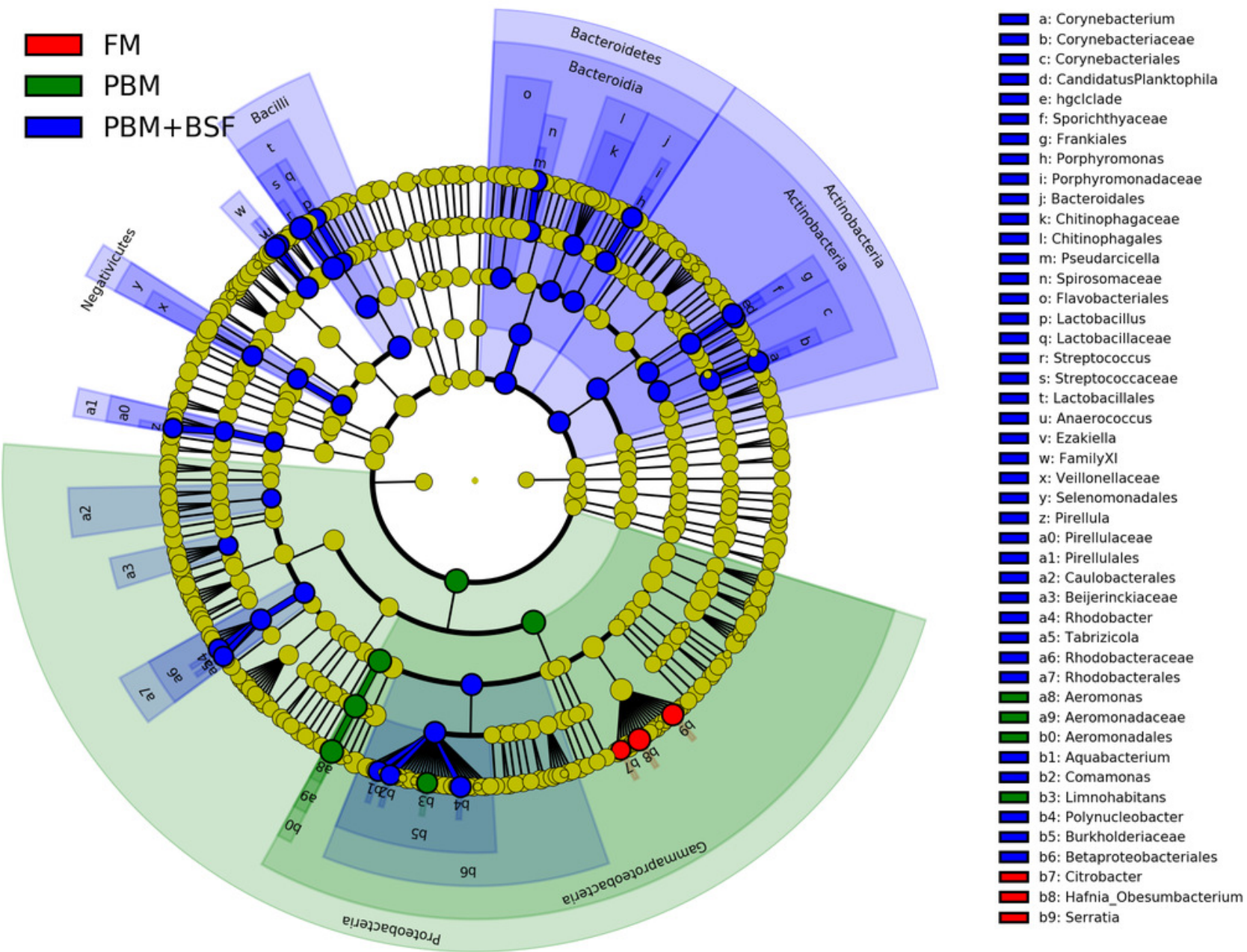


\title{
Figure 5
}

Predicted differentially expressed KEGG metabolic pathways in four different protein fed marron groups identified by Piphillin and linear discriminant analysis (LEfSe), (LDA>3.0, P<0.05).

\author{
Abbreviation: FM = Fishmeal; PBM = Poultry-by-product meal; FM+BSF = Fishmeal + Black \\ soldier fly meal; PBM+BSF = Poultry-by-product meal + Black soldier fly meal.
}

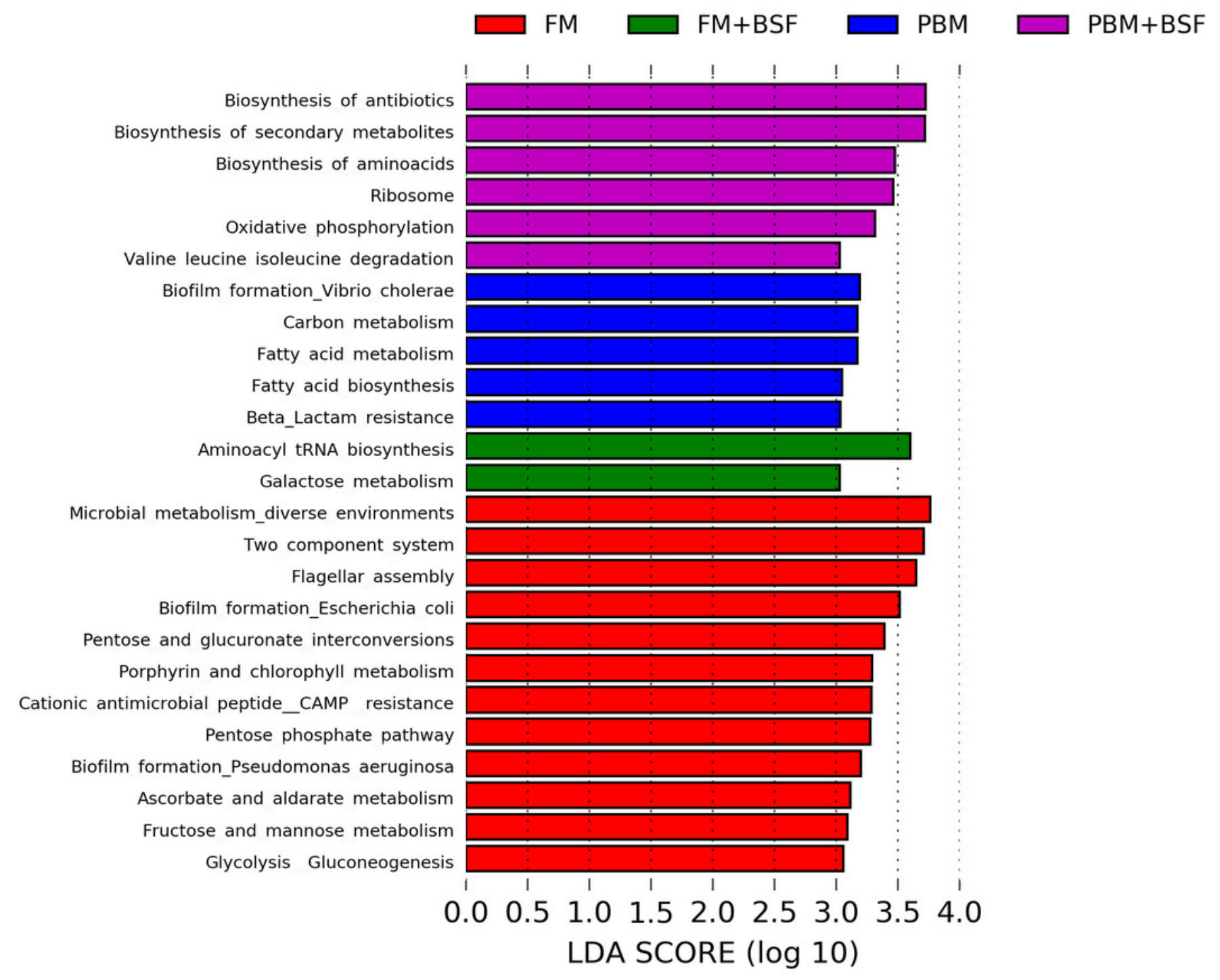




\section{Figure 6}

Relative expression level (Mean $\pm \mathrm{SE}$ ) of major cytokines and crustacean reference genes in marron intestine at the end of 60 days feeding trial.

Means with different superscripts are statistically significant at $\alpha$-level of 0.05 with Duncan's multiple range test.

Abbreviation: FM = Fishmeal; PBM = Poultry-by-product meal; FM+BSF = Fishmeal + Black soldier fly meal; $\mathrm{PBM}+\mathrm{BSF}=$ Poultry-by-product meal + Black soldier fly meal.

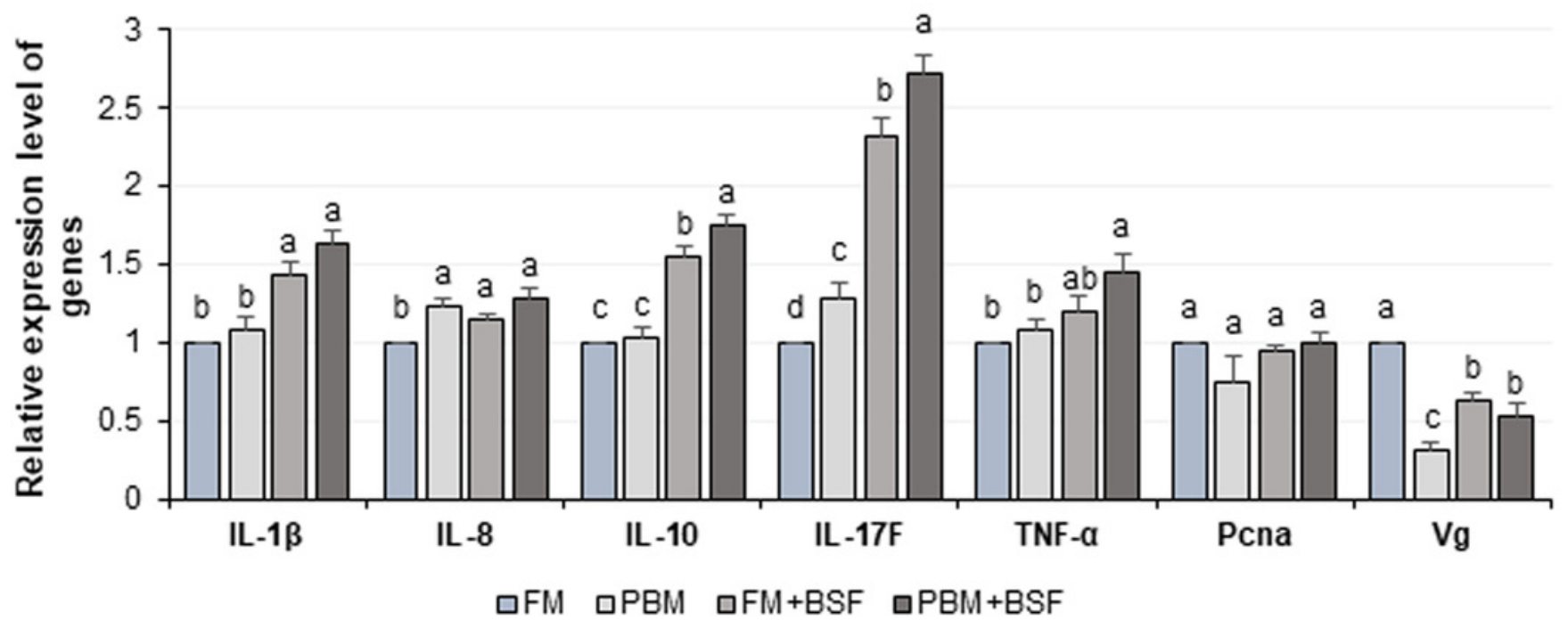

